\title{
Social perception of tree plantations in the Atlantic forest of Argentina: the role of management scale
}

\author{
Lucía Cariola ${ }^{1}$, Andrea E. Izquierdo², Norma Inés Hilgert ${ }^{1,3^{*}}$
}

\begin{abstract}
Land use changes associated with the advance of forest plantations on lands previously used for agriculture generate diverse perceptions of the socio-environmental impact they entail. Despite, these perceptions are influenced by the landscape context produced by the land use changes. In last decades there has been a transformation in land use associated with the development of forestry activity in the northwest of the province of Misiones, Argentina. Considering local communities in order to improve assessment, governance and decisionmaking in sustainable management, we posed two questions: What are environmental, social and economic perceptions of tree plantations of local communities with different land-use context'? What is the role of scale of production in these perceptions? To this purpose we first described the productive matrix of the landscape mapping the forest plantation cover of the area and classifying the productive units in different Forest Management Model (large, medium and small scale).Then, we identified and selected participants from comparable rural communities in each FMM, who through a $Q$ survey grouped phrases according their perceptions. Subsequently, emerging viewpoints were recognised. Our analysis shows that forestry activity is not poorly conceived in contrast to conceptualization of the management of larger-scale productive systems in combination with government policies promoting them. The management carried out through large areas that result in a homogenization of the landscape are perceived negatively. In general terms, the local imagination perceives that the promotion and establishment of forestry companies could be positive if it is supported on planning to protect pre-existing familiar productive systems.
\end{abstract}

Keywords: Tree Plantations; Agricultural Productive Systems; Monoculture Plantations; Perception of Environment; Sustainable Land-Use Planning; Local Livelihood; Well-Being

\footnotetext{
${ }^{1}$ Centro de Investigaciones del Bosque Atlántico (CelBA). Bertoni 85 - N3370AIA / Puerto Iguazú, Misiones - ARGENTINA. Email: lucia.cariola@gmail.com

2 Instituto de Ecología Regional, Universidad Nacional de Tucumán. CONICET. CC 34, CP 4107 Yerba Buena, Tucumán ARGENTINA. E-mail: aeizquierdo@gmail.com

${ }^{3}$ Instituto de Biología Subtropical, Universidad Nacional de Misiones/CONICET.Facultad de Ciencias Forestales, UNaM. Bertoni 85 - N3370AIA / Puerto Iguazú, Misiones - ARGENTINA. E-mail: normahilgert@yahoo.com.ar
}

* Corresponding author. $\mathrm{E}$ E-mail address: normahilgert@yahoo.com.ar 


\section{INTRODUCTION}

Land use change is one of the main conservation concerns (e.g. Lambin et al. 2011). Such changes determine both, environmental (e.g. Vitousek et al.1997) and social aspects (Kasperson et al. 1995) which interact on multiple levels and factors. The expansion of industrial tree plantation is a land use that involves changes of various kinds in the landscape and in the local population. Such changes often generate conflicts among stakeholders (Gerber 2011). The local population, environmental organizations and part of the academic sector highlight issues of environmental damage or lack of equity in the distribution of resources and benefits; they argue that this type of production impedes achieving the objectives of social and environmental sustainability (Andersson et al. 2015). In part in order to achieve these, the importance of the human dimension in nature conservation has increasingly been recognized (e.g. Díaz et al. 2018); however studies concerning the social impacts of forestry remain already underrepresented on the management and conservation research (Dhubháin et al. 2009).

The human dimension research should involve a "learning process" (Korten 1980; Kottak 1999) listening to the local people in order to consider their needs and interest. Knowing how the environment and the land use changes are perceived, offers a tool for the generation of inclusive local development policies in which local and scientific knowledge are recognized as valid and considered useful complementary manifestations that enrich the understanding of processes (Chan et al. 2012; Meijaard et al. 2013; Pascual et al. 2017; Tengo et al. 2014). For these complementarity would be balanced between both types of knowledge; the local process should be considered on the whole. Based on the definition of perception as the way in which the knowledge is used (Oviedo 2004) both phases of the local knowing process are integrated on the study of perception. That is how the information based on local knowledge and perception allows the development of basic indicators that can be applied on a regional scale without ignoring the particularities of each case (Díaz et al. 2018).

With that aim, the perception of stakeholders and local communities in contexts of agricultural and landscape change has been study object in different part of the world. For example, Tatlıdil et al. (2009) analysed how farmers of the northeastern of Turkey perceived sustainable agricultural practices as a previous step to the development and implementation of policies aimed at this type of agriculture. In Europe, Bayfield et al. (2008) presented an analysis of perception contemplating possible future scenarios on land-use with the aim of predicting landscape changes and providing an adequate context for the application of environmental policies. Dhubháin et al. 2009 investigated the social impact of forestry in two areas of Ireland by analysing the current perception of local people. In all cases, they evidenced that rely on local voices can generate new opportunities for conservation and development. Increasingly, new viewpoints highlight the need to consider local communities- among a wide range of stakeholders- on improving assessment, governance and associated decision-making (Díaz et al. 2018).

In the northeast of Argentina, Misiones is currently undergoing an accelerated process of demographic transition and changes in patterns of land use (Izquierdo et al. 2008). 
One of the main trends has been the increase in forestry plantations, mainly Pinus and Eucalyptus (Izquierdo et al. 2008). These forestry plantations are mainly established and managed by large forestry companies and, to a lesser extent, by small to medium-size producers who have ventured into the activity as a result of market growth and government subsidies. As result is possible to identify different productive matrix in which rural communities live. To address the understanding of the local perception of the socio-ecological context of communities under forestry land use changes, we asked: What are the environmental, social and economic perceptions of local communities on their landscape matrix according to the scale of management (i.e. large companies, medium companies, and familiar plantations). According to comparative studies of communities (Kujawska et al. 2017), we developed a similar approach in the three cases analysed. The results allow us to compare the perception of the three different forestry industrial landscapes.

\section{MATERIAL AND METHODS}

\section{Study area}

We conducted this study in the Province of Misiones, Northeast Argentina (Fig.1). The territory now including the province of Misiones was the region with the largest population in Argentina by the middle of the 18th century (INDEC 1980); during the 18th century, the population declined due to Jesuits expulsion and several wars in the region. In 1881, the federal government implemented a colonization program to promote agriculture (Avellaneda Act); colonies were established mainly in long parcels which ensured access to main trails and water sources (Belastegui 2006). This spatial configuration still remains in the study area.

Historically, the land use patterns of the region were selective lodging and slash and burn agriculture. In general, local farmers developed small scale a monocultural agricultural systems (Yerba mate -llex paraguariensis-, citrus or afforestation); and/or mixed farming systems following a model of family farming, with land tenure were the dominant land uses. Work in the farm is carried out by family members, with the occasional hiring of workers and a relative chance of capital accumulation (Chifarelli 2010; Furlan et al. 2015). Between 1973 and 2006, the area dedicated to forestry plantations increased from 1 to $\sim 10 \%$ of the surface of the province (Izquierdo et al. 2008). This increase consisted mainly of exotic pine and Eucalyptus plantations, and to lesser extent plantations of the native Araucaria angustifolia. Simultaneously, with reforestation, there was an intense and sustained process of concentration of land property. Currently the landscape configuration shows small and medium agriculture productive systems surrounded by monoculture tree plantations with different extension and management (Mastrángelo and Trpin 2011).

\section{Spatial analysis and selection of localities and participating families}

To describe the forestry productive landscape matrix, we mapped the forestry plantations cover by visual interpretation of the 2010 LANDSAT TM image at 1: 50,000 scale and information from forestry companies. According this information, we classified tree plantations according to extension and management variables in 


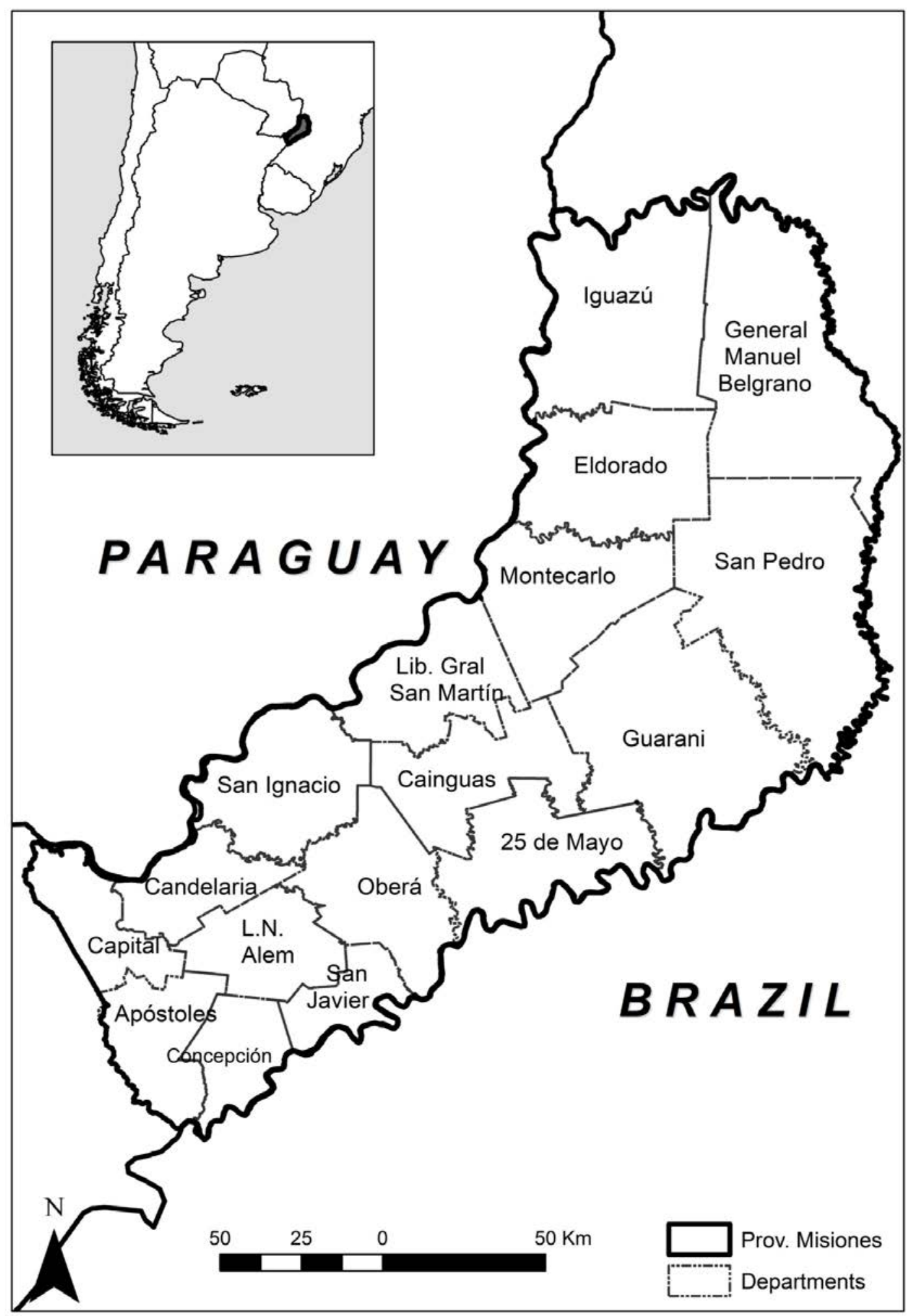

Figure 1. Study Area 
three categories: "large companies", "medium-sized companies" and "familiar plantations" (Table 1). Each category represents a type of forestry model management (FMM).

We identified a total of $14.885 \mathrm{~km}^{2}$ of forestry plantations; $2,198 \mathrm{~km}^{2}$ in "large companies" owned by a single company ( $\mathrm{L}$ FMM); $460 \mathrm{~km}^{2}$ for "medium companies" distributed in 9 owners (M FMM) (C); and a total of $12,227 \mathrm{~km}^{2}$ of "familiar plantations" (F FMM) distributed in 3069 individual production units (D) (Figure 2).

We identified colonies, places and localities close to the three productive situations were identified (large companies, medium and familiar plantations). In each of the three productive situations, we selected local farmers comparable in terms of origin and socio-cultural characteristics at the time of arrival to the region. These communities have in common that they were originated from colonist settlements in the early twentieth century (Belastegui 2006).
Inhabitants have shared cultural characteristics and their time of settlement was similar and prior to forestry development.

\section{Analysis of tree plantations local perception}

In the selected communities we analyze the communities's perceptions about the environmental, sociocultural and political factors that shape their region and we compared these results according to the surrounding FMM. To analyse perceptions, we applied a $Q$ methodological study (Barry and Proops 1999; Brown 1980; Van Exel and Graaf 2005; Webler et al. 2009). This method has the advantage of it enables to compare in a consistent and direct way participant responses (Webler et al. 2009). The $Q$ Method is an inverse factorial analysis in which variables and cases are inverted, i. e. the cases are statements that represent the variability of opinions in the

Table 1. Variables used for the characterization of the different FMMs and the results of this characterization in identifying actors. Number and surface of productive units under each identified FMM.

\begin{tabular}{|c|c|c|c|}
\hline Variables & Large company & $\begin{array}{l}\text { Medium-sized } \\
\text { companies }\end{array}$ & $\begin{array}{l}\text { Familiar } \\
\text { plantations }\end{array}$ \\
\hline Management area & $>130 \mathrm{~km}^{2}$ & $10-129 \mathrm{~km}^{2}$ & $<10 \mathrm{~km}^{2}$ \\
\hline Land ownership & Owner & $\begin{array}{l}\text { Mixed } \\
\text { (owners and } \\
\text { tenants) }\end{array}$ & $\begin{array}{l}\text { Owners } \\
\text { (with } \\
\text { property } \\
\text { title or } \\
\text { occupancy } \\
\text { permit) }\end{array}$ \\
\hline Capital & $\begin{array}{l}\text { Foreign } \\
\text { Multinational }\end{array}$ & National & Locals \\
\hline $\begin{array}{l}\text { Employment } \\
\text { opportunities } \\
\text { (employees / ha) }\end{array}$ & Low & Middle & $\begin{array}{l}\text { None or } \\
\text { Low }\end{array}$ \\
\hline $\begin{array}{l}\text { Degree of } \\
\text { Mechanization }\end{array}$ & High & Middle & Low \\
\hline Market access & $\begin{array}{l}\text { National / } \\
\text { international }\end{array}$ & $\begin{array}{l}\text { National / } \\
\text { international }\end{array}$ & Local \\
\hline
\end{tabular}




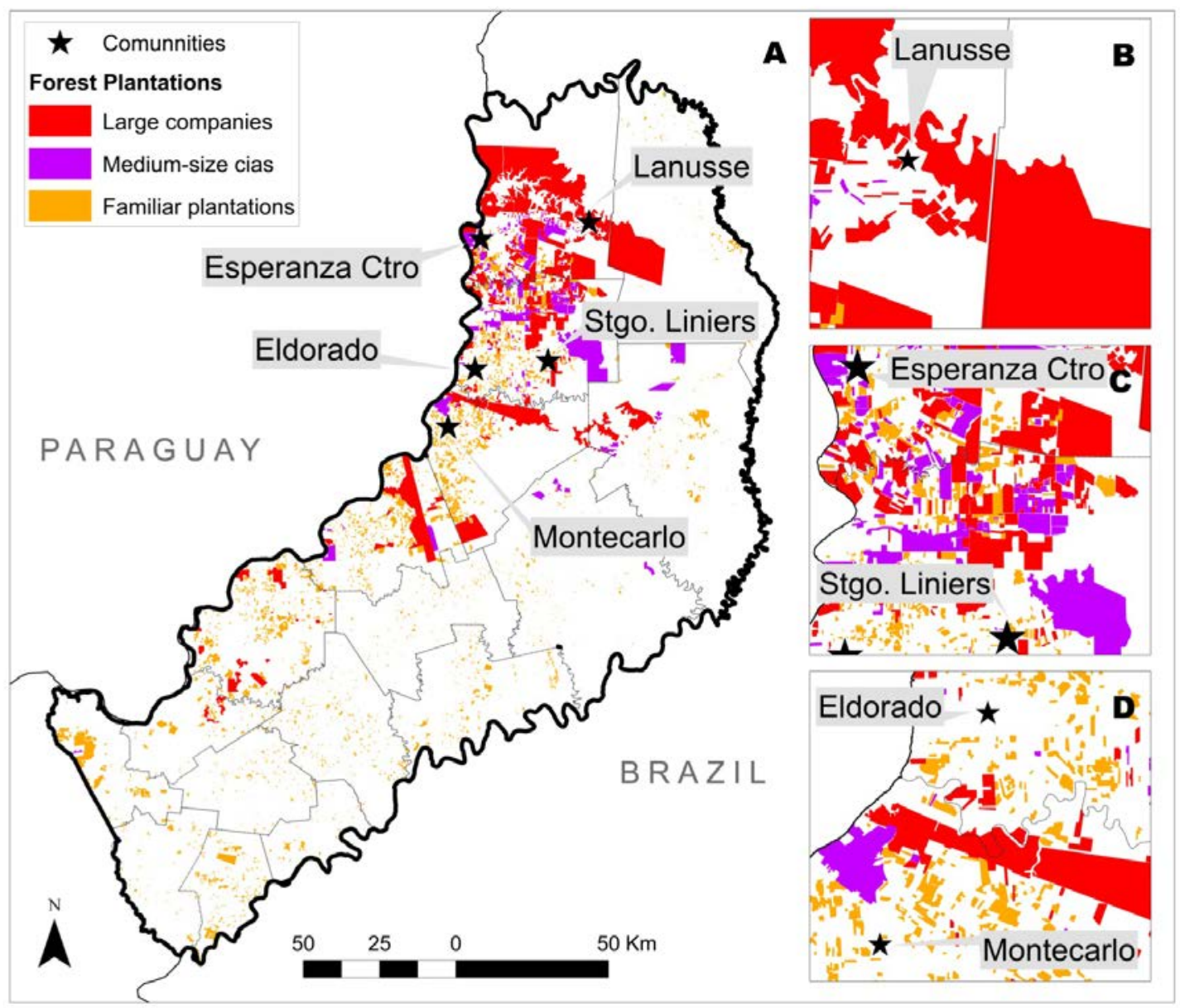

Figure 2. Forestry plantations classified on management models (A) and selected communities neighbouring to the different models: Lanusse communities L FMM (B); Esperanza Centro y Santiago de Liniers communities M FMM (C), and Eldorado and Montecarlo communities F FMM (D).

studied group and each variable is the arrangement each respondent makes of the statements. In general terms, in order to reveal the different social perceptions on a topic, a sample of statements is used. Statements were previously collected from semi-structured interviews did as first step of the study. To do the statement selection the appointment frequency of each topic was taken into account during the interviews. In other words, the most repeated statements were considered. Participants sort the statements into a template according to the degree of agreement they assign (Fig. 3).
The group of ordinations of all the participants is then analysed by correlation and factorial analysis. In this way, patterns are identified depending on the way in which participants related the phrases (i. e. who thinks about the issue in question and what they think).

Through factor analysis, the number of variables - identified perceptions - is reduced to a few factors (3 to 7 ) or unobserved variables (i.e. "summary of perspectives"). Each factor emerging from the analysis groups respondents with similar views on the issue and is defined by the significant 


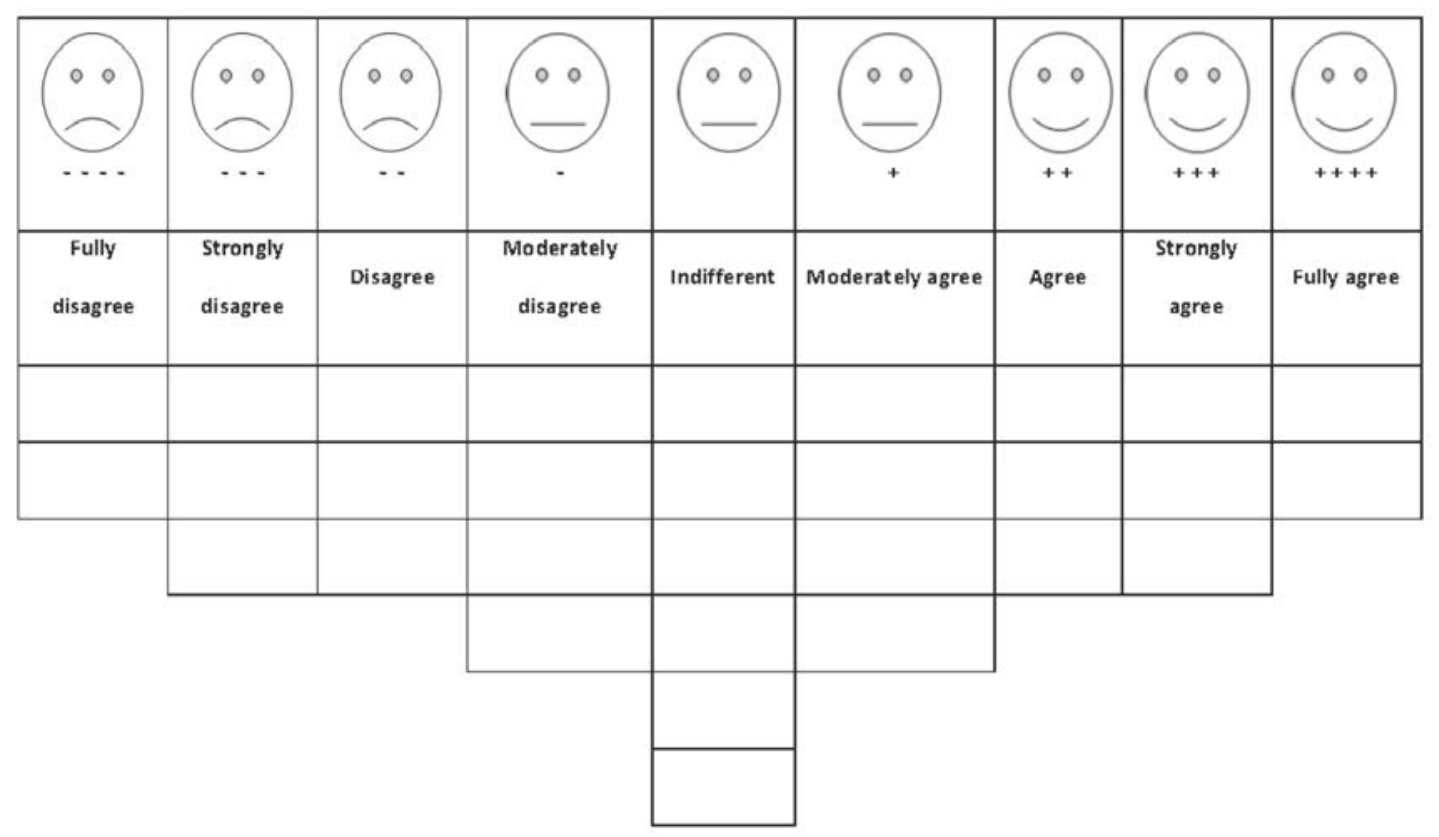

Figure 3. $Q$ survey valuation template.

factorial loads that express the participants' degree of agreement with that factor. In this way, response patterns are identified based on the distribution of statements allowing to evaluate the causes that model participants' perception. In other words, the exposed results do not represent the perception of a particular person but rather an emerging representative perception of the participants grouped in each factor identified in the analysis. Each factor, therefore, represents a collective imaginary. With the objective to identify each one we assign ita name that characterize and trying to describe the prevailing view.

First, we performed 58 semi-structured interviews from August 2012 to November 2013 , covering the history both of the family and the production system of the interviewees (initial area, first crops, purchase or sale of lots, changes affecting production, etc.). From these interviews, we identified topics influencing the perception of forestry activity. Based on these topics, we wrote 30 statements grouped into 6 general topics (own productive system -3 statements-, family economy -9-, environment -6-, social -11-, demographic -6-, government policies -4-) that expressed the participants' emerging opinions. The topics included were selected taking into account the appointment frequency during the interviews. We took into accountwording and syntax in order to people with different levels of literacy understand them. Finally, we selected the participants using a relation of 3:1 between statements and interviewees (Webler et al. 2009). The selection included the greatest possible qualitative variability (Stenner and Marshall 1996). The variability associated with other factors that may be influencing the participant viewpoint was also taken into account (a- holding the farm or not; b- residence in rural or urban environment and c- direct or indirect economic relationship with forestry activity). 
A total of 30 participants were selected (9 colonos living in the farm and 12 living in the city, 5 of whom maintain their productive unit) and 9 participants directly or indirectly related to the regional agroforestry activity (forestry workers, entrepreneurs, teachers). Oral informed consent was obtained (ISE 2006, with 2008 additions).

We asked each respondent individually to classify cards with statements according to their own degree of agreement or disagreement, in two stacks. Then, they had to sort the cards in a valuation template with columns representing different degrees of agreement and a normal distribution (Figure 2 ); covering all cells. During this task, participants were asked to explain the card sorting that they have carried out. To analyse the data, we performed a principal component analysis (PCA) using the $P Q$ Method program (Schmolck 2014; Webler et al. 2009). The number of factors was selected taking the auto-values $>1.0$ as criteria; and a rotation was made by the Varimax. The selection of emerging factors (representing viewpoints) was based on the following criteria: (i) auto-values > 1.0; (ii) at least two participants with significant load per factor; and (iii) the result of multiplying the loads of the actors with the greatest weight in each factor must exceed twice the standard error of the factor score (z-point) (Van Exel and Graaf 2005).

As proposed by Webler et al. (2009) based on the PCA results for each FMM, characterizing, distinctive and consensus statements were identified. For this purpose, we considered: a- Standardized score by factor of the sentences with greater and lesser agreement respectively (characterizing statements), whose values of $Z$ score did not show significant differences with the proposed cut-off value $(<0.05)$. b- Z punctuation values greater than
1 of the distinguishing statements with significant statistical differences (significance levels $<0.05$ and $<0.01$ were recognized) and therefore significantly associated with a given factor. Of the later those coinciding with the characterizing statements were considered. c- Values of $Z$ score of consensus statements, i.e. those present in all the factors emerging in the analysis. dWe compared the statements with greater and lesser differences in $Z$ score of the factors that provide a greater percentage of variability in each sorting. As a criterion to identify the statements with the greatest differences, $Z$ score values $>1.50$ were established; to identify the lowest differences, we took $Z$ scores with values between $-0.3<x<0.3$. e- The socio-cultural characteristics of people identified as representing the different local perceptions (i.e. those with the highest factor load per factor) were considered.

Finally, we made an ethnographic comparison of the main emergent factors identified in the perception among inhabitants neighboring to each FMM. In order to characterize the general perception of the population of each FMM, the emerging viewpoints in each micro-region were previously identified. We then compared key phrases that met the above criteria and considered repeatable and consensus statements.

Details on the $Q$ classifications and their results are given for each FMM. Additional file I details results related to "large companies" FMM (L FMM), additional filex II details the "medium-size companies" FMM (M FMM), additional file III details the "familiar plantations" FMM (F FMM) and additional filex IV includes a general valuation assigned to statements by participants neighbouring the three FMM. Each Additional File includes tables whose 
name is the corresponding additional file number followed by the order of the table within the additional file (e. g. Table I. 1; Table I. 2, etc.). In Table x. 1. the distinctive and characterizing statements integrating each factor are cited. In Table $x$. 2. the sentences expressing consensus between factors in the general issues addressed in the classification are detailed (i. e. own productive system, family economy, environment, social, demographic and governmental policies). In Table x. 3 . phrases with greater and lesser differences between factors are analysed in detail. And in Tables x. 4 and x. 5 characteristics of neighbours grouped into the factors explained are offered.

\section{RESULTS}

\section{Perception analyses}

From the PCA analysis, three factors were identified explaining $65 \%$ of the variance in the case of L FMM; four factors explaining $67 \%$ of the variance in M FMM and four explaining $68 \%$ of the variance for $F$ FMM (Table 2).

From the emerging perceptions defined by the inhabitants of the different productive landscapes, we observe shared and nonshared aspects. There are common valuations that allow a general characterization of how the group perceives the environment and how they position

\begin{tabular}{|c|c|c|c|c|c|c|c|c|c|c|c|}
\hline \multirow[b]{2}{*}{ Factors } & \multicolumn{3}{|c|}{ LARGE FMM } & \multicolumn{4}{|c|}{ MEDIUM FMM } & \multicolumn{4}{|c|}{ FAMILIAR FMM } \\
\hline & 1 & 2 & 3 & 1 & 2 & 3 & 4 & 1 & 2 & 3 & 4 \\
\hline $\begin{array}{l}\text { No. of participants } \\
\text { defining factor ( } Q \\
\text { sorts) }\end{array}$ & 3 & 4 & 3 & 2 & 4 & 2 & 2 & 3 & 3 & 2 & 2 \\
\hline $\begin{array}{l}\text { Average reliability } \\
\text { coefficient }\end{array}$ & 0.800 & 0.800 & 0.800 & 0.800 & 0.800 & 0.800 & 0.800 & 0.800 & 0.800 & 0.800 & 0.800 \\
\hline Reliability & 0.923 & 0.941 & 0.923 & 0.889 & 0.941 & 0.889 & 0.889 & 0.923 & 0.923 & 0.889 & 0.889 \\
\hline SE & 0.277 & 0.941 & 0.923 & 0.333 & 0.243 & 0.333 & 0.333 & 0.277 & 0.277 & 0.333 & 0.333 \\
\hline $\begin{array}{l}\text { Total variance } \\
\text { explained (\%) }\end{array}$ & 23 & 24 & 18 & 18 & 20 & 15 & 14 & 23 & 18 & 14 & 13 \\
\hline Total \% explained & \multicolumn{3}{|c|}{65} & \multicolumn{4}{|c|}{67} & \multicolumn{4}{|c|}{68} \\
\hline
\end{tabular}

Table 2. Characteristics of the factors obtained through PCA analysis by FMM ${ }^{1}$

1 Table values correspond to the factor characterizations results of each Principal Components Analysis. No. of participants defining factor ( $Q$ sorts): is the number of interviewees that characterize the factor. Average reliability coefficient: is the expected correlation between two responses given by the same interviewee (Zabala and Pascual 2016). Reliability: is the founded correlation between two responses given by the same interviewee. SE: is the standard error for each factor. Total variance explained (\%): is the total variance explained referred to each factor. Total \% explained: is the total variance explained referred to the total analysis. 
themselves with respect to the six main topics considered in the evaluation (Additional File IV). This additional file compares the emerging assessment of the 30 key phrases among the three FMM (according to their representation as a characterizing phrase and the observed internal consensus).

Among the classifications made by the participants communities L FMM, three factors were defined and named: environmentalists, critics and conciliators. Environmentalists do not express a critical view of afforestation, although there is a weak emerging viewpoint highlighting the negative impact on the environment. Critics groups participants who express negative perceptions both in social aspects and in relation to government policies. Conciliators' perception focuses on social and environmental aspects (with negative and positive characteristics). In general terms and with a high degree of agreement, the three profiles consider forestry activity as a productive innovation that got to the region with the establishment of companies but they state that there are other better productive alternatives, both at regional and familiar level (Additional File I).

For the M FMM, four factors were defined: Impartials, who point out the impact the forest activity exertson the family productive system, the environment and the social aspect, detractors, who also observe the impact on family production and the commercialization of forest products, and two other groups (family production and health and government, local and regional production) that include divided opinions on the same topics: those who perceive problems in relation to family production and health and those who do so in relation to government and local and regional production (with negative considerations for the first aspect) (Additional File II).

For the F FMM, four factors were defined; Impartials, they are not critical, they weakly point out objections in relation to the impact of forestry activity on the environment; intellectuals, represented by participants who have acceded to higher education and intellectualize the problem; they have a negative opinion in relation to the environment, demographic -emigration- and social factors -ways of communication-; commercial monopoly (as the name implies, they perceive that forestry companies compete with the small producer); and familiar activity versus activity in companies, those who perceive a dichotomy between family and business activity generally with a negative perception (if companies prosper small producers do not and vice versa) (Additional File III).

\section{Comparison of perception between communities of different FMM}

Differences and concordances are observed when we analyse the overall aspects included in the statements ordered (Additional File IV). Regarding demographic aspects, the perception that the expansion of large-scale plantations has a direct relationship with depopulation in rural areas is highlighted in F FMM where different opinions arise (Statement 23, hereinafter we state only the number, Additional File IV shows each of these statements). The fact that the depopulation of rural areas favoured the extension of forest plantations (26) is highlighted in $M$ FMM where different opinions also emerge. L FMM disagrees in what refers to forest development and the reduction of goods and services in rural areas (24). The fact that activities at company level will affect family growth is highlighted in LFMM which does not show 
agreement (25).

Regarding the environment, in L FMM this aspect does not emerge as part of the collective imagination. M FMM highlights the benefits of the colonos' diversified production system (12) and the impact of afforestation on springs and streams (9); forest production is not considered better than other monocultures (11). The impact on biodiversity (10) and own crops is highlighted in F FMM, although different opinions arise (8).

On the social aspects, $L$ and $F$ FMM agree that afforestation is not the best productive option (19) while M FMM shows a diversity of opinions. In relation to the loss of working capacity for families on the farm when one of their members goes to work in the forestry company (18), L FMM and F FMM do not agree while M FMM shows a diversity of opinions. L FMM highlights the lack of improvements in transport and communications infrastructure in the colony with the settlement of companies (16). In M FMM they show a diversity of opinions about the relationship between forest plantations and the neighbours health (17). And they do not consider the relationship between companies and neighbours to be as good as in F FMM (21). In the latter case (i.e. $F$ FMM), they see no relationship between the increase in plantations and lower social activity (22). There are different opinions regarding the increase in associated jobs (13) but they do not see a decrease in the labour supply as a consequence of forestry companies' mechanization (14).

Regarding the aspects related to own productive system, $L$ and $F$ FMM agree that afforestation in the respective zones developed since the establishment of companies (3), while M FMM shows a diversity of opinions. In L FMM they do not consider that colonos have neglected their productive activities as a result of forestry development (1). In the F FMM they emphasize that the latter allowed families to have alternatives other than agricultural production (2).

With regard to the family economy, there is a general agreement that there is currently no competition between large and small producers (5). However, both L FMM and F FMM agree that forestry companies monopolise and regulate the conditions for the marketing of forest products (4), which could be related to an international market assumption in the monopolisation.

With regard to government policies, there are different opinions in $\mathrm{L} F M M$ regarding the need to regulate the activity (27). Both $L$ FMM and $F$ FMM agree that policies favoured large capitals (28). F FMM emphasizes that government policies did not guarantee the well-being of the local population despite the region's economic growth (30).

\section{DISCUSSION}

This study provides information on how people living in different landscapes defined by a different forest management model, evaluate forest activity. The methodological approach allows for an analysis at two levels.

On the one hand, at the intragroup level, from the comparison of the viewpoints identified inside the three FMM, environmental conceptualizations that each one makes could be influenced by subjective aspects such as feelings or emotions linked to the personal experiences. We also find that the socio-economic characteristics taken into account for this analysis (qualification, the source of family income or the type of productive system of each farmer) are also involved in their perception. 
On the other hand, the second level of analysis is among the three FMM where the explanations given have to do with the structural changes that have occurred in the environment.

In the comparison inside each FMM, it is relevant that the group that shows a less critical perception of the impact of forestry activity is formed mainly by those that currently continue to be rural producers, i.e. whose base their economy on farm products. Those neighbours who have abandoned agriculture (generally due to a professionalization of labour) usually show a more "intellectual" criticism of how productive development in the region should be promoted. This could be related to a higher educational level and probably a livelihood changes with a major accessibility to urbanization. Both tendencies respond to similar patterns found in studies carried out in Chile that evaluated preference of habitat among inhabitants with different proximity -physical, productive and conceptual- to the countryside and forestry activity. It was found that the distance to afforestation partially modulates their perception and the inhabitants closest to the stands tend to have a more neutral position in this regard (Püschel-Hoeneisen and Simonetti 2012).

In the comparison between FMM and in order to understand the vision local inhabitants build of their environment, we must take into account the forestry history and characteristics of each colony. In general we can differentiate two perceptions, one in which more critical aspects about forestry activity emerge and the other with opposite valuations. The first group includes neighbours of $L F M M$ and part of those of $M$ FMM and the other group includes neighbours of $F$ FMM and the rest of those of M FMM. How can we interpret the lack of consensus among the neighbours of $M$
FMM. According to Webler et al. (2009), the issues considered in the same viewpoint can be evaluated by interviewees in an opposite way. The difference in the assessments observed is probably influenced by the differences in the structure of the productive landscape in which the colonies are immersed. Taking this hypothesis into account, in accordance with observations in other parts of the world (Barr 2008) and depending on the changes in the agrarian experience in the study area, two large typologies of landscape can be considered. The Lanusse (L FMM) and Esperanza (M FMM) cases are communities with more intensified production of large forestry areas and with a declining rural population. Both colonies are surrounded by forestry plantations in large blocks, have a population that has been declining for several decades and currently have access to a limited number of goods and services (IPEC 2015). Santiago de Liniers, Eldorado and Montecarlo show more diversified productive landscapes with a more stable rural population. Santiago de Liniers (M FMM), Eldorado and Montecarlo (F FMM). Santiago de Liniers presents heterogeneity in the landscape that is close to that observed in the matrix defined as F FMM; the largest forest enterprise is a mediumsized company owned by dispersed plantations with small and medium plots separated from each other. The last three colonies show population growth (IPEC 2015) and relatively better access to goods and services.

At the same time, at the community structure level -within the forest stands- it was found that plantations with greater diversity (as a result of less intensive management) are perceived as better (Püschel-Hoeneisen and Simonetti 2012); probably the same perceptive logic operates 
in the valuation of the studied region, but on a landscape scale. It will be very interesting to test these assumptions in future work. In a context that once again shows the complexity in modelling perception, but also in coincidence with the general emerging concept, in Borneo there were more negative perceptions of afforestation for industrial purposes as the landscape included more and larger stands; with the consequent reduction of the remnants of original forest (primarily in relation to the impact on the environment,with high levels of concern about increasing temperatures, air pollution and the loss of clean water sources) (Meijaard et al. 2013). On the other hand, this latest work found that as more time goes by since the original forest landscape was transformed, there is a greater balance in the valuation of the benefits and damages associated with the activity (Meijaard et al. 2013). Perceptual process that, if a part of human mechanisms of adaptation to change, could imply a risk in the collective conception of the conservation of the original environment and biodiversity.

The emerging aspects that model the colonos in the northwest of Misiones refer to processes that have been taking place in the area for decades and are coincident with those cited in scientific studies on reforestation and socio-environmental conflicts in other parts of the world, such as changes in the size and composition of rural populations and neighboring cities, in the use of and access to natural resources, employment opportunities, rural infrastructure, goods and services, communication and transport routes (Chan et al. 2012; Charnley 2005; Leys and Vanclay 2010; Meijaard et al. 2013; Pramova et al. 2012; Sodhi et al. 2010; Williams and Schirmer 2012).

Often, perception studies require complementary analyses that allow for triangulating results and providing more complete scenarios (Bayfield et al. 2008). This case is a first approximation to the differences in landscapes resulting from changes in land use. As such, it makes clear the need for complementary studies that allow for comprehensive approaches to the problematic. Despite we analysed contrasting profiles a small number of participants could be considered given the characteristics of the study. The sample could be not representative and different results may be found even with people of similar characteristics. In a second step it would be necessary to propose an analysis that would cover a representative population and would make it possible to compare the found results.

\section{CONCLUSIONS}

Demographic, environmental, social, own productive system, family economy and government policies are considered as determining factors in regional history. In the studied area, from a general perspective, forestry itself is not poorly conceptualized in contrast to the conceptualization of management of larger-scale productive systems in combination with government policies promoting them. In the local imaginary, the promotion and establishment of forestry companies are perceived as a mistake, without planning to protect preexisting familiar productive systems.

The comparison of the viewpoints identified in the three FMM shows shared perceptions related to the conceptualization of the environment made by each participant. Past experiences and socioeconomic characteristics (education, the source of family income or the type of productive system of each farmer) seem to 
be involved. In this case, it is relevant that the group with a relatively positive perception of forestry activity is composed mainly by producers. On the other hand, the explanations given under certain viewpoints are related with the structural changes in the productive landscape.

This study is framed in research on mixed methods of analysis of bio-physical variables and in approaches to the social perception that have opened new opportunities for dealing with land use change (Bieling 2013). The combination of techniques on geographic information systems (GIS) and specific perception analysis allow to identify the way local people understand their environment according to three forest management models that condition the type of landscape they live in. From their own explanation of the environment it is possible to see how they perceive themselves as affected by different types of productive landscapes. The obtained information reveals the real differences in the way afforestation is recognised, highlights concrete facts and could contribute to political decision-making (Steelman and Maguire 1999).

In a generalization these results from our study case, could show that incorporating into governments' agenda the cosmovision, local interests and values when drawing up policies for productive development and socio-cultural promotion should be a indispensable concern (Díaz et al. 2018; Pascual et al. 2017). In land-use change contexts, economic and productive issues and differences in power between stakeholders are the most frequent sources of conflict (Paruelo et al. 2014). Considering the perception of these changes by the most vulnerable group becomes a priority for the development of policies for sustainable territorial planning (Paruelo 2011).

\section{ACKNOWLEDGEMENTS}

Our special thanks to the inhabitants of the study site, who kindly assisted us and shared their experience and wisdom. As well we thank to CONICET and CEDIT for the Postgraduate Grant of Lucía Cariola. We are also grateful to Antonio de la Peña Garcia for help in the early stage of this study, to Diego Chifarelli for his participation in one workshop, to Gustavo Zurita for the reviewed of the manuscript, to Quenia de los Santos for her help in the tables' design, and to Haydée González for the linguistic revision. This project was funding by ARGIS/G53 of PNUD, UCAR-MAGyP (PIA 10103, BIOSilva, scholarship program), FONCYT PICT 2015-1578 and CONICET Project UE IBS.

\section{REFERENCES}

Andersson K, Lawrence D, Zavaleta J, Guariguata M (2015) More trees, more poverty? The socioeconomic effects of tree plantations in Chile, 2001-2011. Environmental Management 57:123-136.

Barr N (2008) Landscape analysis and visualisation. Berlin, Heidelberg: Springer. Lecture Notes in Geoinformation and Cartography

http://www.springerlink.com/index/10.1007/9783-540-69168-6

Barry J, Proops J (1999) Seeking sustainability discourses with $\mathbf{Q}$ methodology. Ecological Economics 28:337-345.

Bayfield N, Barancok P, Furger M, et al. (2008) Stakeholder perceptions of the impacts of rural funding scenarios on mountain landscapes across urope. Ecosystems doi:10.1007/s10021-008-9197-1

Belastegui HM (2006) Los colonos de Misiones. Ed. Universitaria de Misiones. Posadas, Argentina.

Bieling C (2013) Perceiving and responding to gradual landscape change at the community level: Insights from a case study on agricultural abandonment in the Black Forest, Germany. Ecology and Society doi:10.5751/ES05590-180236 
Brown SR (1980) Political subjectivity: Applications of $Q$ methodology in political science. Yale University Press, USA

Chan KMA, Guerry AD, Balvanera P, Klain S, Satterfield T, Basurto X, Bostrom A, et al. (2012) Where are cultural and social in ecosystem services? A framework for constructive engagement. Bio Science 62:744-756.

Charnley S (2005) Industrial Plantation Forestry: Do Local Communities Benefit? Journal of Sustainable Forestry 21:59-73.

Chifarelli D (2010) Acumulación, éxodo y expansión. Un análisis sobre la agricultura familiar en el norte de Misiones. Ediciones INTA, Buenos Aires, Argentina

Díaz S, Pascual U, Stenseke M, Martín-López B, Watson RT, Molnár Z, Hill R, et al. (2018) Assessing nature's contributions to people. Recognizing culture, and diverse sources of knowledge, can improve assessments. Science 359:6373 http://science.sciencemag.org

Dhubháin ÁN, Fléchard MC, Moloney R, O'Connor D (2009) Stakeholders' perceptions of forestry in rural areas-Two case studies in Ireland. Land Use Policy doi: 10.1016/j.landusepol.2008.09.003

Furlan V, Cariola L, García D, Hilgert NI (2015) Caracterización de los sistemas agroforestales familiares y estrategias de uso del ambiente en el Bosque Atlántico Argentino. Gaia Scientia 9:69-81.

Gerber JF (2011) Conflicts over Industrial Tree Plantations in the South: Who, How and Why? Global Environmental Change doi:10.1016/j.gloenvcha.2010.09.005

IPEC -Instituto Provincial de Estadísticas y Censos- (2015) Gran Atlas de Misiones. Posadas, Misiones, Argentina http://www.ipecmisiones.org/gran-atlas-demisiones

ISE (2006) International Society of Ethnobiology Code of Ethics (with 2008 additions) http://ethnobiology.net/code-ofethics/Accessed 28 August 2015

Izquierdo AE, Angelo CD De, Aide T M (2008) Thirty years of human demography and landuse change in the Atlantic Forest of Misiones, Argentina: An evaluation of the forest transition model. Ecology and Society http://www.ecologyandsociety.org/vol13/iss2/art3/
Kasperson JX, Kasperson RE, Turner BL II (eds.) (1995) Regions at risk: comparisons of threatened environments. United Nations Univ. Press, Tokyo

Korten DC (1980) Community organization and rural development: A learning process approach. Public Administration Review 910:480-512

Kottak CP (1999) The new ecological anthropology. American Anthropologist 101:2335.

Kujawska M, Hilgert NI, Keller HA, Gil G (2017) Medicinal Plant Diversity and Inter-Cultural Interactions between Indigenous Guarani, Criollos and Polish Migrants in the Subtropics of Argentina. PLOS ONE doi:10.1371/journal.pone.0169373

Lambin EF, Meyfroidt P (2011) Global land use change, economic globalization, and the looming land scarcity. Proceedings of the National Academy of Sciences 108: 3465-3472.

Leys A, Vanclay J (2010) Land-use change conflict arising from plantation forestry expansion: Views across Australian fencelines. International Forestry Review doi/abs/10.1505/ifor.12.3.256

Mastrángelo A, Trpin V (comps) (2011) Entre chacras y plantaciones. Trabajo rural y territorio en producciones que Argentina exporta. Edit. CICCUS, Buenos Aires, Argentina

Meijaard E, Abram NK, Wells JA, Pellier AS, Ancrenaz M, Gaveau DLA, Runting RK, Mengersen K (2013) People's perceptions about the importance of forests on Borneo. PLoS ONE doi:10.1371/journal.pone.0073008

Oviedo JL (2004) La definición del concepto de percepción en psicología con base en la teoría Gestalt. Revista de Estudios Sociales 18:89-96.

Paruelo JM (2011) Valoración de servicios ecosistémicos y planificación del uso del territorio ¿Es necesario hablar de dinero? Capítulo 5. En: Laterra P, Jobbágy EG, Paruelo JM (eds.). Valoración de servicios ecosistémicos: conceptos, herramientas y aplicaciones para el ordenamiento territorial. MAG/INTA, Argentina 
Paruelo JM, Laterra P, Viglizzo E (2014) Un plan operativo para incorporar los servicios ecosistémicos en el proceso de ordenamiento territorial. En: Paruelo JM, Jobbágy EG, Laterra P, Diéguez H, Collazo MG, Paniza A (eds.) Ordenamiento Territorial: Conceptos, Metodologías y Experiencias. UBA/MAG/FAO, Buenos Aires, Argentina

Pascual U, Balvanera P, Díaz S, Pataki G, Roth E, Stenseke M, Watson RT, et al. (2017) Valuing nature's contributions to people: the IPBES approach. Current Opinion in Environmental Sustainability 26-27:7-16 https://www.sciencedirect.com/science/article/pii/ S1877343517300040?via\%3Dihub

Pramova E, Locatelli B, Djoudi H, Somorin OA (2012) Forests and trees for social adaptation to climate variability and change. Wiley Interdisciplinary Reviews: Climate Change 3:581-596.

Püschel-Hoeneisen N, Simonetti JA (2012) Forested habitat preferences by Chilean citizens: Implications for biodiversity conservation in Pinusradiata plantations. Revista Chilena de Historia Natural 85:161-169.

Schmolck P (2014) PQ method. Retrieved October 162014.

Sodhi N, Lee T, Sekercioglu C, Webb E, Prawiradilaga DM, Lohman DJ, Pierce NE, Diesmos AC, Rao M, Ehrlich PR (2010) Local people value environmental services provided by forested parks. Biodiversity and Conservation 19:1175-1188.

Steelman TA, Maguire LA (1999) Perspectives: Q-methodology in national forest management. Journal of Policy Analysis and Management 18:361-388.
Stenner P, Marshall H (1996) A Q methodological study of rebelliousness. European Journal of Social Psychology 25:612-636.

Tatlidil F, Boz I, Tatlidil H (2009) Farmers' perception of sustainable agriculture and its determinants: A case study in Kahramanmaras province of Turkey. Environment, Development and Sustainability doi:10.1007/s10668-008-9168$x$

Tengo M, Brondizio ES, Elmqvist T, Malmer P, Spierenburg M (2014) Connecting diverse knowledge systems for enhanced ecosystem Governance: The multiple evidence base approach. AMBIO doi: 10.1007/s13280-0140501-3

Van Exel J, Graaf G.d (2005) Q methodology: A sneak preview. Social Sciences 2:1-30 http://qmethod.org/articles/vanExel.pdf.

Vitousek PM, Mooney HA, Lubchenco J, Melillo JM (1997) Human domination of earth's ecosystems. Science 277:494-499.

Webler T, Danielson S, Tuler S (2009). Using Q method to reveal social perspectives inenvironmental research. Greenfield MA: Social and Environmental Research Institute. http://www.seri-

us.org/sites/default/files/Qprimer.pdf

Williams KJ, Schirmer J (2012) Understanding the relationship between social change and its impacts: The experience of rural land use change in south-eastern Australia. Journal of Rural Studies 28:538-548.

Zabala A, Pascual U (2016) Bootstrapping Q methodology to improve the understanding of human perspectives. PloS ONE 11 e0148087
Received: 24 June 2018

Accepted: 15 August 2018

Published: 19 October 2018 


\section{ADDITIONAL FILES I. PERCEPTION OF L FMM COMMUNITIES. Summary of the characteristics of the main emerging points of view.}

The analysis identified three main factors that represent the collective imaginary. According to these factors three groups were defined and named: environmentalists, critics and conciliators. Each factor brings together (through significant factor loads) participants with similar views on the issue. The name assigned to each factor was defined taking into consideration the theme -or emotional position- emerging in relation to forestry activity and its impacts. Table 3 of the article details the reliability, error and percentage of explained values of each factor, as well as the total percentage of explained with the factors considered.

The following is a description of each identified factor. For further details, please refer to the tables in the Additional File. Table I. 1. lists distinguishing and characterizing statements. Table I. 2. details statements expressing consensus between factors referred to general issues addressed in the classification (i.e. own productive system, family economy, environment, social, demographic and governmental policies). In Table I. 3. analyses statements with greater and lesser differences between factors in detail. Tables I. 4. and I. 5. characterize the neighbours grouped in each factor explained.

There are issues considered common and most relevant by the participants of the L FMM. They observe that due to the high vehicular traffic the activity implies, companies could have expanded, improved or contributed to the maintenance of roads in their area of influence. However, they consider that none of this happened. On the contrary, they perceive that some roads were cancelled and others deteriorated, complicating the transit of settlers in rainy seasons. They do not associate the establishment of companies with institutional retraction (closure of schools and health posts). They consider that maintaining production on the farm is not affected when a family member spends their time working in the company. As for the relationship between family and forest production business, they agree that companies monopolize and regulate the conditions of commercialization but without creating competition in the local market. They argue that regional forestry development policies favoured large capitals and, with a partial agreement, state that at present the activity should be more regulated (Table IV 2).

\section{Factor 1: The Environmentalists.}

From these viewpoint participants highlight the consequences of forestry activity on the environment, neighbours health and own productive system. Forestry production is considered to be the least friendly (regarding other monocultures such as tobacco or soy) (11); it is related to the decrease in the volume of water in streams and to drying springs (9) and it is considered to put neighbours health at risk due to the increase in water, soil and air pollution (in the latter during flowering due to the increase of pollen) (17). On the positive side, the establishment of companies in the area is considered to have created direct and indirect jobs (2). 
Two of the participants with high loads for this factor are producers (P10) but one of them combines agricultural and extra-farm activity as he is employed in a forestry company (P9). In these two cases, there is a direct and indirect link to business afforestation. The third one is a son of producers currently retired as a teacher. He worked in the colony at the time of the analysed changes (P4) (Tables I. 4 and I. 5).

\section{Factor 2: The critics.}

All participants grouped here have a critical view of the situation, both socially and in relation to government policies. The emerging idea is that the presence of business activity did not lead to an increase in the supply of jobs either in urban (13) or rural areas, the latter being the result of the activity mechanization (14). Regarding the implemented government policies, it is not perceived that they have favoured medium or small producers nor have they foster economic growth in the region (29).

The four participants with high loads for this factor have been professionalized (P2, P3 and P5). Three of them are not linked to agriculture. The fourth is currently a rural producer and combines agricultural activity with extra-farm activity (P1) (Tables I.4 and I.5).

\section{Factor 3: The conciliators.}

The emerging viewpoint in this factor focuses on social and environmental aspects. With regard to the first, it is not perceived that the decrease in social activity is linked to the development of forestry companies (22), although it is considered that there is a deterioration of roads due to the intense use by companies (15). In relation to the environment, at the business or family level this activity is not considered to affect the production of neighbouring farms and it is not related to the increase of pests $(7,8)$.

Two of the participants showing high loads for this factor are producers with extra-farm activities (P6 and P7). The third is a teacher at a school in the colony (P8) (Tables I. 4 and I. 5).

In summary, when we compare factors 1 and 2 (which explain a higher percentage of variability according to the results of the Principal Components analysis) (Table I. 2.), the statements with the greatest differences in the $Z$ score are associated with own productive system when we consider whether the establishment of companies allowed families to have alternatives other than agricultural production (2). In social terms, they do not agree on the relationship between the development of forestry activity and the increase in jobs mainly in urban areas (13) (Table I. 3).

The viewpoints are similar in relation to social aspects and do not perceive that the hiring of family producers in forestry companies implies neglecting their own productive systems (18). With regard to the family economy, they do not consider that there is competition between companies and small producers (5); finally, regarding the commercialization of the product they consider, that forestry companies monopolize and regulate marketing conditions (4) (Table I. 1. and I. 2.). 
Table I. 1. Distinguishing and characterizing statements.

\begin{tabular}{|c|c|c|c|}
\hline \multicolumn{4}{|c|}{ Factor 1: The Environmentalists } \\
\hline & $\begin{array}{c}\begin{array}{c}\text { Distinguishing Statements that match with characterizing } \\
\text { statements }\end{array} \\
\end{array}$ & $\begin{array}{l}\text { Q sort } \\
\text { value }\end{array}$ & $\begin{array}{l}\text { Z-scores } \\
(P<0.01)\end{array}$ \\
\hline \multirow[b]{2}{*}{ Environment } & 9. Pines consume a lot of water and the streams dry up. & 4 & $1.49^{\star}$ \\
\hline & $\begin{array}{l}\text { 11. Plantations are better for the environment than other industrial } \\
\text { crops in the area (such as soybeans and tobacco). }\end{array}$ & -4 & $-2.06^{\star}$ \\
\hline Social & $\begin{array}{l}\text { 17. Fumigations and pollen from forestry plantations affect } \\
\text { neighbours health. }\end{array}$ & 4 & $1.46^{*}$ \\
\hline \multirow[t]{2}{*}{$\begin{array}{l}\text { Own productive } \\
\text { system }\end{array}$} & $\begin{array}{l}\text { 2. The establishment of forestry companies allowed families to } \\
\text { have other productive activities (such as trade, employment, } \\
\text { contractors, etc.). }\end{array}$ & 3 & $1.44^{*}$ \\
\hline & Characterizing statements & $\begin{array}{l}Q \text { sort } \\
\text { value }\end{array}$ & Z-scores \\
\hline \multirow{3}{*}{ Demographic } & $\begin{array}{l}\text { 23. The change in landscape with the increase in forestry } \\
\text { plantations (companies), contributed to the migration of colonos to } \\
\text { cities. }\end{array}$ & -3 & -1.54 \\
\hline & $\begin{array}{l}\text { 24. With the development of forestry, schools and rural health posts } \\
\text { were closed. }\end{array}$ & -3 & -1.48 \\
\hline & $\begin{array}{l}\text { 26. The abandonment of farms, by the migration of colonos to } \\
\text { cities, allowed the advancement of forestry plantations. }\end{array}$ & 3 & 1.06 \\
\hline \multirow{2}{*}{ Social } & $\begin{array}{l}\text { 16. Forestry companies open more roads in the colony and this is } \\
\text { good for families living in the area. }\end{array}$ & -4 & -1.59 \\
\hline & $\begin{array}{l}\text { 19. Plantations are the best productive activity both for the region } \\
\text { and for local families. }\end{array}$ & -3 & -1.54 \\
\hline Family economy & $\begin{array}{l}\text { 4. Forestry companies monopolize and regulate the marketing } \\
\text { conditions of forestry products (wood and pulp). }\end{array}$ & 3 & 1.03 \\
\hline
\end{tabular}

\begin{tabular}{|c|c|c|c|}
\hline \multicolumn{4}{|c|}{ Factor 2: The critics } \\
\hline & $\begin{array}{c}\text { Distinguishing Statements that match with characterizing } \\
\text { statements }\end{array}$ & $\begin{array}{l}\text { Q sort } \\
\text { value }\end{array}$ & $\begin{array}{l}\text { Z-scores } \\
(P<0.01)\end{array}$ \\
\hline \multirow{2}{*}{ Social } & $\begin{array}{l}\text { 13. With the development of forestry activity there is more work in } \\
\text { the colony. }\end{array}$ & -4 & -1.58 \\
\hline & $\begin{array}{l}\text { 14. The mechanization of forestry companies decreased the } \\
\text { demand for labour. }\end{array}$ & 4 & 1.77 \\
\hline \multirow[t]{2}{*}{$\begin{array}{l}\text { Government } \\
\text { policies }\end{array}$} & $\begin{array}{l}\text { 29. Government policies, which promoted forestry activity, have } \\
\text { brought economic growth to the region. }\end{array}$ & -3 & -1.47 \\
\hline & Characterizing statements & $\begin{array}{l}\text { Q sort } \\
\text { value }\end{array}$ & $\begin{array}{c}\text { Z- scores } \\
\text { Matching distinguishing } \\
\text { statements with significant } \\
\text { differences indicated with an } \\
\text { asterisk }(\mathrm{P}<0.05) \text {. }\end{array}$ \\
\hline Environment & $\begin{array}{l}\text { 10. With forestry activity, earth bugs (worms, beetles, etc.) die and } \\
\text { it is more difficult to find some animals (pigs, yatei bees) and } \\
\text { plants from the forest that we use (for medicine, to eat). }\end{array}$ & 3 & $1.60^{*}$ \\
\hline \multirow{3}{*}{ Social } & $\begin{array}{l}\text { 19. Plantations are the best productive activity both for the region } \\
\text { and for local families. }\end{array}$ & -4 & -2.25 \\
\hline & $\begin{array}{l}\text { 20. Forestry companies should contribute more to the } \\
\text { development of education, health and landscape restoration in the } \\
\text { municipalities where they are located. }\end{array}$ & 4 & 1.85 \\
\hline & $\begin{array}{l}\text { 21. The relationship between forestry companies and neighbours } \\
\text { is good. }\end{array}$ & -3 & -1.05 \\
\hline $\begin{array}{l}\text { Own productive } \\
\text { system }\end{array}$ & $\begin{array}{l}\text { 3. Forestry plantations were already part of the local productive } \\
\text { activity before the establishment of companies in the colony. }\end{array}$ & -3 & -1.14 \\
\hline Family economy & $\begin{array}{l}\text { 4. Forestry companies monopolize and regulate the marketing } \\
\text { conditions of forestry products (wood and pulp). }\end{array}$ & 3 & 1.30 \\
\hline $\begin{array}{l}\text { Government } \\
\text { policies }\end{array}$ & $\begin{array}{l}\text { 28. Regional forestry development policies favoured large } \\
\text { capitals. }\end{array}$ & 3 & 0.87 \\
\hline
\end{tabular}




\begin{tabular}{|c|c|c|c|}
\hline \multicolumn{4}{|c|}{ Factor 3: The conciliators } \\
\hline & $\begin{array}{l}\begin{array}{l}\text { Distinguishing Statements that match with characterizing } \\
\text { statements }\end{array} \\
\end{array}$ & $\begin{array}{l}Q \text { sort } \\
\text { value }\end{array}$ & $\begin{array}{l}Z \text {-scores } \\
(P<0.01)\end{array}$ \\
\hline \multirow{2}{*}{ Environment } & $\begin{array}{l}\text { 7. With large plantations, there are more pests that damage } \\
\text { neighbouring farms. }\end{array}$ & -3 & -1.11 \\
\hline & $\begin{array}{l}\text { 8. Fumigations of forestry plantations damage some family } \\
\text { productions (honey, citrus, corn, cassava, yerba mate). }\end{array}$ & -3 & -1.14 \\
\hline \multirow{3}{*}{ Social } & 15. The intensive use of roads causes damage to rural dwellers. & 3 & 1.52 \\
\hline & $\begin{array}{l}\text { 22. The decrease in social activities among the colony neighbours } \\
\text { (clubs closures, abandonment of typical festivities, etc.) is related } \\
\text { to the establishment of forestry activity in the colony. }\end{array}$ & -4 & -2.17 \\
\hline & Characterizing statements & $\begin{array}{l}\text { Q sort } \\
\text { value }\end{array}$ & $\begin{array}{c}\text { Z- scores } \\
\text { Matching distinguishing } \\
\text { statements with significant } \\
\text { differences indicated with an } \\
\text { asterisk }(\mathrm{P}<0.05) \text {. }\end{array}$ \\
\hline Demographic & $\begin{array}{l}\text { 24. With the development of forestry, schools and rural health } \\
\text { posts were closed. }\end{array}$ & -4 & -1.87 \\
\hline Environment & $\begin{array}{l}\text { 12. The typical productive activity of the colonos (with a little bit of } \\
\text { everything, pigs, yerba mate, cassava, etc.) is better for the } \\
\text { environment than plantations. }\end{array}$ & 4 & $1.76^{*}$ \\
\hline Social & $\begin{array}{l}\text { 16. Forestry companies open more roads in the colony and this is } \\
\text { good for families living in the area. }\end{array}$ & -3 & -1.04 \\
\hline \multirow[b]{2}{*}{ Family economy } & $\begin{array}{l}\text { 4. Forestry companies monopolize and regulate marketing } \\
\text { conditions of forestry products (wood and pulp). }\end{array}$ & 4 & $2.07^{\star}$ \\
\hline & $\begin{array}{l}\text { 6. The salaries of forestry companies increase the amount of } \\
\text { money circulating in the region and improve commercial activity } \\
\text { (buying and selling of food, clothing, telephones, etc.). }\end{array}$ & 3 & 1.00 \\
\hline $\begin{array}{l}\text { Government } \\
\text { policies }\end{array}$ & $\begin{array}{l}\text { 28. Regional forestry development policies favoured large } \\
\text { capitals. }\end{array}$ & 3 & 1.31 \\
\hline
\end{tabular}

Table I. 2. Consensus Statements.

\begin{tabular}{|c|c|c|c|c|c|c|c|}
\hline \multirow{2}{*}{\multicolumn{2}{|c|}{ Consensus Statements }} & \multicolumn{2}{|c|}{ Factor 1} & \multicolumn{2}{|c|}{ Factor 2} & \multicolumn{2}{|c|}{ Factor 3} \\
\hline & & Q-value & $\begin{array}{l}\text { Z-score } \\
(P<0.01)\end{array}$ & Q-value & $\begin{array}{l}\text { Z-score } \\
(P<0.01)\end{array}$ & Q-value & $\begin{array}{l}\text { Z-score } \\
(P<0.01)\end{array}$ \\
\hline Social & $\begin{array}{l}\text { 18. When a farmer dedicates to forestry } \\
\text { activity in a company, family members } \\
\text { have less help in caring for the farm. }\end{array}$ & 0 & -0.16 & 0 & -0.1 & 0 & 0 \\
\hline \multirow{2}{*}{$\begin{array}{l}\text { Own } \\
\text { productive } \\
\text { system }\end{array}$} & $\begin{array}{l}\text { 1. Due to the offer of new jobs, with the } \\
\text { establishment of forestry companies, the } \\
\text { inhabitants neglect some productive } \\
\text { activities in their farms. }\end{array}$ & 0 & 0.21 & -1 & -0.53 & -1 & -0.56 \\
\hline & $\begin{array}{l}\text { 3. Forestry plantations were already part } \\
\text { of the local productive activity before the } \\
\text { establishment of companies in the colony. }\end{array}$ & -1 & -0.32 & -3 & -1.14 & -2 & -0.82 \\
\hline $\begin{array}{l}\text { Family } \\
\text { economy }\end{array}$ & $\begin{array}{l}\text { 5. Forestry companies compete with small } \\
\text { producers in the local market. }\end{array}$ & -1 & -0.4 & -1 & -0.32 & 0 & 0.07 \\
\hline $\begin{array}{l}\text { Government } \\
\text { policies }\end{array}$ & $\begin{array}{l}\text { 27. Government policies should further } \\
\text { regulate forestry activity. }\end{array}$ & 0 & -0.13 & 2 & 0.77 & 0 & 0.1 \\
\hline
\end{tabular}


Table I. 3. Comparison of statements of greater and lesser differences in the $Z$ score between factor 1 and factor 2 of $L$ FMM.

\begin{tabular}{|l|l|l|l|l|}
\hline \multicolumn{1}{|c|}{ Statements of greater differences between factors } & \multicolumn{1}{|c|}{ Sector } & Factor 1 & Factor 2 & Difference \\
\hline $\begin{array}{l}\text { 2. The establishment of forestry companies allowed families to have other } \\
\text { productive activities (such as trade, employment, contractors, etc.). }\end{array}$ & $\begin{array}{l}\text { Own productive } \\
\text { system }\end{array}$ & 1.435 & -1.049 & 2.484 \\
\hline $\begin{array}{l}\text { 13. With the development of forestry activity there is more work in the } \\
\text { colony. }\end{array}$ & Social & -0.077 & -1.580 & 1.503 \\
\hline
\end{tabular}

\begin{tabular}{|l|l|l|l|l|}
\hline \multicolumn{1}{|c|}{ Statements of lesser differences between factors } & \multicolumn{1}{|c|}{ Sector } & Factor $\mathbf{1}$ & Factor $\mathbf{2}$ & Difference \\
\hline $\begin{array}{l}\text { 18. When a farmer dedicates to forestry activity in a company, family } \\
\text { members have less help in caring for the farm. }\end{array}$ & Social & -0.162 & -0.098 & -0.065 \\
\hline 5. Forestry companies compete with small producers in the local market. & Family economy & -0.401 & -0.316 & -0.086 \\
\hline $\begin{array}{l}\text { 4. Forestry companies monopolize and regulate marketing conditions for } \\
\text { forestry products (wood and pulp). }\end{array}$ & Family economy & 1.029 & 1.303 & -0.274 \\
\hline
\end{tabular}

Table I. 4. Summary of the characteristics of the main factors of the L FMM analysis.

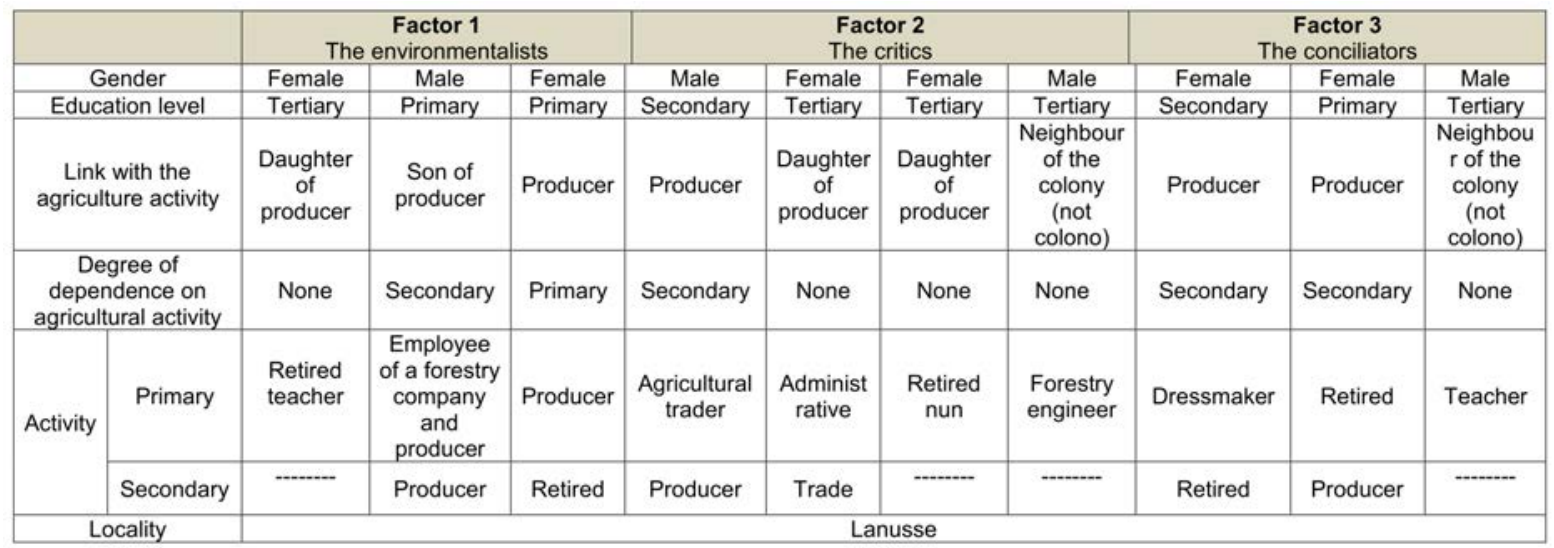

\section{REFERENCES:}

The degree of dependence on agricultural activity: Principal: main source of livelihood; Secondary: when the satisfaction of family needs is based on another type of productive activity in addition to agricultural activity; none: the informant does not develop agricultural activities.

Productive activity (or of sustenance): Principal: activity with greater importance to the family sustenance; Secondary: activity with less importance to the family sustenance. 
Table I. 5. Characteristics of the participants and factorial loads.

\begin{tabular}{|l|c|c|c|c|}
\hline \multicolumn{1}{|c|}{ Factorial loads of the analysis of L FMM } & $\begin{array}{c}\text { The degree of } \\
\text { dependence on } \\
\text { agricultural activity }\end{array}$ & $\begin{array}{c}\text { Factor } \mathbf{1} \\
\text { The environmentalists }\end{array}$ & $\begin{array}{c}\text { Factor } \mathbf{2} \\
\text { The critics }\end{array}$ & $\begin{array}{c}\text { Factor } \mathbf{3} \\
\text { The conciliators }\end{array}$ \\
\hline Daughter of producers, $\mathrm{ft}$ & None & $\mathbf{0 . 6 2}^{\mathbf{b}}$ & 0.31 & 0.21 \\
\hline Son of producers, $\mathrm{mp}$ & Secondary & $\mathbf{0 . 7 9}^{\boldsymbol{b}}$ & 0.09 & 0.003 \\
\hline Producer, $\mathrm{fp}$ & Primary & $\mathbf{0 . 8 7}^{\boldsymbol{b}}$ & -0.11 & 0.21 \\
\hline Producer, $\mathrm{ms}{ }^{\boldsymbol{a}}$ & Primary & -0.23 & $\mathbf{0 . 6 9}^{\boldsymbol{b}}$ & 0.37 \\
\hline Daughter of producers, $\mathrm{ft}$ & None & 0.44 & $\mathbf{0 . 6 6}^{\boldsymbol{b}}$ & 0.24 \\
\hline Daughter of producers, $\mathrm{ft}$ & None & 0.49 & $\mathbf{0 . 7 3}^{\boldsymbol{b}}$ & -0.09 \\
\hline Neighbour of the colony (not colono), $\mathrm{mt}$ & None & 0.04 & $\mathbf{0 . 8 3}^{\boldsymbol{b}}$ & -0.12 \\
\hline Producer, fs & Secondary & 0.09 & 0.26 & $\mathbf{0 . 6 8}^{\boldsymbol{b}}$ \\
\hline Producer, $\mathrm{fp}$ & Secondary & 0.14 & 0.10 & $\mathbf{0 . 7 9}^{\boldsymbol{b}}$ \\
\hline Neighbour of the colony (not colono), $\mathrm{mt}$ & None & 0.10 & -0.22 & $\mathbf{0 . 6 2}^{\boldsymbol{b}}$ \\
\hline
\end{tabular}

REFERENCES: Gender: $m=$ male; $f=$ female. Education level: $p=$ primary; $s=s e c o n d a r y ; t=t e r t i a r y ;$ u=university. Colony: EC=Esperanza Centro; $S L=$ Santiago de Liniers. b Significant factorial loads. 


\section{ADDITIONAL FILES II. PERCEPTION OF M FMM COMMUNITIES.}

\section{Summary of the characteristics of the main emerging points of view.}

The analysis identified the main factors that represent the collective imaginary. Each factor brings together participants with similar views on the issue(from significant factor loads reflecting the degree of agreement). The name assigned to each factor was defined by the authors taking into consideration the theme -or emotional position- emerging in relation to forestry activity and its repercussions. Table 3 of the article details the reliability, error and percentage of explained values of each factor, as well as the total percentage of explained with the factors considered.

For this FMM, four factors were defined and named as the impartial group, the critical group, plus two other groups that include divided opinions on the same topics, those that perceive problems in relation to family production and health and those that do so in relation to government and local and regional production. For further details refer to the tables in this Additional File. Table II. 1. lists distinguishing and characteristic statements that integrate each factor. In Table II. 2. details statements expressing consensus between factors in the general issues addressed in the classification (i. e. own productive system, family economy, environment, social, demographic and governmental policies). In Table II. 3. analyses statements with greater and lesser differences between factors. Tables II. 4. and II. 5. characterize the neighbours grouped into the factors explained.

The issues considered as common and most relevant by the inhabitants the M FMM often generate opposing viewpoints. Among the participants of Esperanza Centro, there is a tendency to make more negative evaluations than among those of Santiago de Liniers. This lack of consensus is evident when analysing the relationship between rural-urban migration and advance of forest plantations, in which the participants of each colony agree but there is no agreement between colonies. When we evaluate the historical moment in which forestry activity was incorporated to the region, there was agreement only among the participants of Santiago de Liniers. In relation to the association between pests and monoculture growth, no consensus was found in any case nor do participants agree when they consider the importance of these productive systems at a regional and local level.

There was also no agreement on the impact on health of fumigation and the profuse pollen releases during flowering; neither on the hiring of producers and its effect on the family farm activities. On the other hand, there is general agreement when the participants argue that possibilities of growth at the family level were not affected by the activity of forest companies; they do not perceive a relationship of commercial competition between companies and small producers since they consider each is oriented towards a different market; they perceive the relationship between forest companies and their neighbours as negative. There is also agreement on claiming the productive and environmental benefits of the diversified system typical of colonos as opposed to monoculture, and on not considering forest plantations as a better alternative to other monocultures. In the same way, they consider that pine plantations consume a lot of water (Additional File IV). 


\section{Factor 1: The Impartials}

From this viewpoint participants consider that forestry activity (pine plantations in particular) has been part of the colonos' productive system since before the establishment of medium and large companies (3). On a larger scale than the family one, afforestation is considered to favour environmental deterioration but not to increase pests (7). In social terms, they highlight the lack of improvement on roads (16).

Participants grouped in this factor live in Santiago de Liniers and are related to each other. One of them is a producer and the other is a teacher who collaborates with rural activities in the family farm (Tables II. 4. and II. 5.).

\section{Factor 2: The detractors}

The emerging viewpoint in this factor highlights that forestry plantations were not a productive activity in the region prior to entrepreneurial development (3). It argues that the small producer is conditional on the sale of his product at the market value established by large capitals and that the marketing conditions are unfair (4). They do not perceive that the hiring of family producers in forestry companies implies that they neglect their own productive systems (18).

This factor includes a neighbour of Santiago de Liniers -producer- (P7) and three from Esperanza Centro, two of them are producers (P3 and P9) and the other is a technician in a public institution who works in family production, and therefore, is aware of the associated problems of the area (P10) (Tables II. 4. and II. 5.).

\section{Factor 3: Divided opinions: family production and health}

This factor brings together those aspects that weigh the consequences of the establishment of companies on their own productive system: it is considered that the hiring of family producers in business forestry activities favoured that they neglect the farm (1). On the other hand, there is no apparent link between neighbours health and forestry activity (17).

This factor is defined by one participant from Santiago de Liniers and another from Esperanza Centro. The informants grouped here consider the same aspects to be relevant, however their assessments are opposed as the sentences were placed in opposite positions. In this case, the Esperanza Centro participant gives positive scores (Tables II. 4. and II. 5.).

\section{Factor 4: Divided opinions: Government, local and regional production}

In relation to government policies, companies are not perceived to be the most benefited (28). Forestry production is also highlighted as the best option at regional and family level (19).

This factor brings together one participant from Esperanza Centro and another from Santiago de Liniers. As in the previous case, both participants consider the same aspects to be relevant. However, their assessments are opposed. In this case, it is the participant from Santiago de Liniers who gives positive scores (Tables II. 4. and II. 5.). 
Finally, when comparing between factors, the $Z$ punctuation sentences with the greatest differences between factors 1 and 2 (which explain a higher percentage of variability) (Table II. 3.) focus on demographics when it is asked whether the forest advance occurred as a result of the abandonment of family productive systems (26); and in relation to own productive system, when it is questioned whether forestry plantations were a productive activity in the region before entrepreneurial development (3).

Concerning to the most similar phrases, in terms of government policies, it is not perceived that they have favored either medium or small producers or foster economic growth in the region (29). Demographically, they argue that the possibilities of growth at family level were not affected by forestry company activities (25) but do not establish a link between rural-urban migration and the advance of forestry plantations (23). In relation to the environment, in these two factors, forestry production is considered to be the least friendly (regarding other monocultures such as tobacco or soybean (11). They claim the typical diversified system of colonos as opposed to monoculture (12) and agree that it affects biodiversity negatively (10). In social terms, they do not consider that there is a deterioration of roads due to intensified use associated with plantations (15) (Table II. 3.).

Table II. 1. Distinguishing and characterising statements.

\begin{tabular}{|c|c|c|c|}
\hline \multicolumn{4}{|c|}{ Factor 1: The impartials } \\
\hline & $\begin{array}{l}\begin{array}{l}\text { Distinguishing Statements that match with characterising } \\
\text { statements }\end{array} \\
\end{array}$ & $\begin{array}{l}\text { Qsort } \\
\text { value }\end{array}$ & $\begin{array}{l}\text { Z-scores } \\
(P<0.01)\end{array}$ \\
\hline Environment & $\begin{array}{l}\text { 7. With large plantations, there are more pests that damage } \\
\text { neighbouring farms. }\end{array}$ & -4 & -1.98 \\
\hline Social & $\begin{array}{l}\text { 16. Forestry companies open more roads in the colony and this is } \\
\text { good for families living in the area. }\end{array}$ & -4 & -1.65 \\
\hline \multirow[t]{2}{*}{$\begin{array}{l}\text { Own productive } \\
\text { system }\end{array}$} & $\begin{array}{l}\text { 3. Forestry plantations were already part of local productive } \\
\text { activity before the establishment of companies in the colony. }\end{array}$ & 4 & 1.65 \\
\hline & Characterising statements & $\begin{array}{l}\text { Q sort } \\
\text { value }\end{array}$ & $\begin{array}{c}\text { Z-scores } \\
\text { Matching distinguishing } \\
\text { statements with significant } \\
\text { differences indicated with } \\
\text { an asterisk }(P<0.05) \text {. }\end{array}$ \\
\hline \multirow{3}{*}{ Demographic } & $\begin{array}{l}\text { 24. With the development of forestry, schools and rural health } \\
\text { posts were closed. }\end{array}$ & 3 & 1.15 \\
\hline & $\begin{array}{l}\text { 25. The productive and economic management of forestry } \\
\text { companies diminished the opportunities for family producers to } \\
\text { produce, save and progress. }\end{array}$ & -4 & -0.93 \\
\hline & $\begin{array}{l}\text { 26. The abandonment of the farms, by the migration of colonos to } \\
\text { cities, allowed the advance of forestry plantations. }\end{array}$ & 4 & 1.87 \\
\hline \multirow[b]{2}{*}{ Environment } & 9. Pines consume a lot of water and the streams dry up. & 3 & 1.15 \\
\hline & $\begin{array}{l}\text { 12. The typical productive activity of the colonos (with a little bit of } \\
\text { everything, pigs, yerba mate, cassava, etc.) is better for the } \\
\text { environment than plantations. }\end{array}$ & 3 & 1.21 \\
\hline \multirow[b]{2}{*}{ Social } & $\begin{array}{l}\text { 19. Plantations are the best productive activity both for the region } \\
\text { and for local families. }\end{array}$ & -3 & -1.49 \\
\hline & $\begin{array}{l}\text { 20. Forestry companies should contribute more to the } \\
\text { development of education, health and landscape restoration in } \\
\text { the municipalities where they are located. }\end{array}$ & -3 & $-1.38^{*}$ \\
\hline
\end{tabular}




\begin{tabular}{|c|c|c|c|}
\hline \multicolumn{4}{|c|}{ Factor 2:The detractors } \\
\hline & Distinguishing Statements that match with characterising statements & $\begin{array}{l}Q \text { sort } \\
\text { value }\end{array}$ & $\begin{array}{l}\text { Z-scores } \\
(P<0,01)\end{array}$ \\
\hline Social & $\begin{array}{l}\text { 18. When a farmer dedicates to forestry activity in a company, family } \\
\text { members have less help in caring for the farm. }\end{array}$ & -3 & -1.02 \\
\hline $\begin{array}{l}\text { Own } \\
\text { productiv } \\
\text { e system }\end{array}$ & $\begin{array}{l}\text { 3. Forestry plantations were already part of the local productive activity } \\
\text { before the establishment of companies in the colony. }\end{array}$ & -4 & -1.77 \\
\hline \multirow[t]{2}{*}{$\begin{array}{l}\text { Family } \\
\text { economy }\end{array}$} & $\begin{array}{l}\text { 4. Forestry companies monopolize and regulate the marketing conditions } \\
\text { for forestry products (wood and pulp). }\end{array}$ & 4 & 1.65 \\
\hline & Characterising Statements & $\begin{array}{l}Q \text { sort } \\
\text { value }\end{array}$ & Z-scores \\
\hline \multirow{3}{*}{$\begin{array}{l}\text { Environm } \\
\text { ent }\end{array}$} & $\begin{array}{l}\text { 7. With large plantations, there are more pests that damage neighbouring } \\
\text { farms. }\end{array}$ & 3 & 1.06 \\
\hline & 9. Pines consume a lot of water and the streams dry up. & 4 & 1.80 \\
\hline & $\begin{array}{l}\text { 12. The typical productive activity of the colonos (with a little bit of } \\
\text { everything, pigs, yerba mate, cassava, etc.) is better for the environment } \\
\text { than plantations. }\end{array}$ & 3 & 1.20 \\
\hline \multirow{4}{*}{ Social } & 15. Intensive use of roads causes damage to rural dwellers. & -4 & -1.15 \\
\hline & $\begin{array}{l}\text { 17. Fumigations and pollen from forestry plantations affect neighbours } \\
\text { health. }\end{array}$ & 3 & 1.48 \\
\hline & $\begin{array}{l}\text { 19. Plantations are the best productive activity both for the region and for } \\
\text { local families. }\end{array}$ & -3 & -2.31 \\
\hline & 21. The relationship between forestry companies and neighbours is good. & -3 & -1.23 \\
\hline
\end{tabular}

\begin{tabular}{|c|c|c|c|}
\hline \multicolumn{4}{|c|}{ Factor 3: Divided opinions: family production and health } \\
\hline & Distinguishing Statements that match with characterising statements & $\begin{array}{l}\text { Q sort } \\
\text { value }\end{array}$ & $\begin{array}{l}\text { Z-scores } \\
(P<0.01)\end{array}$ \\
\hline Social & $\begin{array}{l}\text { 17. Fumigations and pollen from forestry plantations affect neighbours } \\
\text { health }\end{array}$ & -3 & -1.27 \\
\hline \multirow[t]{2}{*}{$\begin{array}{l}\text { Own } \\
\text { productive } \\
\text { system }\end{array}$} & $\begin{array}{l}\text { 1. Due to the offer of new jobs, with the establishment of forestry } \\
\text { companies, the inhabitants neglected some productive activities in their } \\
\text { farms. }\end{array}$ & 4 & 1.58 \\
\hline & Characterising Statements & $\begin{array}{l}\text { Q sort } \\
\text { value }\end{array}$ & Z-scores \\
\hline \multirow{2}{*}{$\begin{array}{l}\text { Demograp } \\
\text { hic }\end{array}$} & $\begin{array}{l}\text { 23. The change in the landscape with the increase in forestry plantations } \\
\text { (companies), contributed to the colonos migration to cities. }\end{array}$ & 3 & 1.27 \\
\hline & $\begin{array}{l}\text { 26. The abandonment of the farms, by migration of colonos to the city, } \\
\text { allowed the advance of forestry plantations. }\end{array}$ & -4 & -1.06 \\
\hline \multirow{3}{*}{ Social } & $\begin{array}{l}\text { 18. When a farmer dedicates to forestry activity in a company, family } \\
\text { members have less help in caring for the farm. }\end{array}$ & 3 & 1.27 \\
\hline & $\begin{array}{l}\text { 19. Plantations are the best productive activity both for the region and for } \\
\text { local families. }\end{array}$ & -3 & -1.79 \\
\hline & 21. The relationship between forestry companies and neighbours is good. & -3 & -1.48 \\
\hline $\begin{array}{l}\text { Own } \\
\text { productive } \\
\text { system }\end{array}$ & $\begin{array}{l}\text { 2. The establishment of forestry companies allowed families to have other } \\
\text { productive activities (such as trade, employment, contractors, etc.). }\end{array}$ & 3 & 1.27 \\
\hline $\begin{array}{l}\text { Family } \\
\text { economy }\end{array}$ & 5. Forestry companies compete with the small producer in the local market. & -3 & -1.79 \\
\hline $\begin{array}{l}\text { Governme } \\
\text { nt policies }\end{array}$ & 27. Government policies should further regulate forestry activity. & 4 & 1.79 \\
\hline
\end{tabular}




\begin{tabular}{|c|c|c|c|}
\hline \multicolumn{4}{|c|}{ Factor 4: Divided opinions: Government, local and regional production } \\
\hline & $\begin{array}{l}\text { Distinguishing Statements that match with characterising } \\
\text { statements }\end{array}$ & $\begin{array}{l}\text { Q sort } \\
\text { value }\end{array}$ & $\begin{array}{l}\text { Z-scores } \\
(P<0,01)\end{array}$ \\
\hline Social & $\begin{array}{l}\text { 19. Plantations are the best productive activity both for the region } \\
\text { and for local families. }\end{array}$ & 3 & 1.37 \\
\hline \multirow[t]{2}{*}{$\begin{array}{l}\text { Government } \\
\text { policies }\end{array}$} & 28. Regional forestry development policies favoured large capitals. & -4 & -1.65 \\
\hline & Characterising statements & $\begin{array}{l}Q \text { sort } \\
\text { value }\end{array}$ & $\begin{array}{c}\text { Z-scores } \\
\text { Matching distinguishing } \\
\text { statements with significant } \\
\text { differences are indicated } \\
\text { with an asterisk }(\mathrm{P}<0.05) \text {. }\end{array}$ \\
\hline Demographic & $\begin{array}{l}\text { 26. The abandonment of farms, by migration of colonos to the city, } \\
\text { allowed the advance of forestry plantations. }\end{array}$ & 3 & 1.09 \\
\hline \multirow{3}{*}{ Environment } & $\begin{array}{l}\text { 8. Fumigations of forest plantations damage some family } \\
\text { productions (honey, citrus, corn, cassava, yerba mate). }\end{array}$ & 4 & 1.64 \\
\hline & 9. Pines consume a lot of water and the streams dry up. & 4 & 2.19 \\
\hline & $\begin{array}{l}\text { 10. With the forestry activity, earth bugs (worms, beetles, etc.) die } \\
\text { and it is more difficult to find some animals (pigs, yatei bees) and } \\
\text { plants from the forest we use (for medicine, to eat). }\end{array}$ & -4 & $-1.64^{\star}$ \\
\hline Social & $\begin{array}{l}\text { 17. Fumigations and pollen from forestry plantations affect } \\
\text { neighbours health of . }\end{array}$ & 3 & 1.37 \\
\hline \multirow[b]{2}{*}{ Family economy } & $\begin{array}{l}\text { 5. Forestry companies company competes with the small producer } \\
\text { in the local market. }\end{array}$ & -4 & -1.10 \\
\hline & $\begin{array}{l}\text { 6. The salaries of forestry companies increase the amount of } \\
\text { money circulating in the region and improve commercial activity } \\
\text { (buying and selling of food, clothing, telephones, etc.). }\end{array}$ & -3 & $-1.38^{*}$ \\
\hline $\begin{array}{l}\text { Government } \\
\text { policies }\end{array}$ & $\begin{array}{l}\text { 30. Despite the region's economic growth, government policies do } \\
\text { not guarantee the well-being of the local population. }\end{array}$ & -4 & -1.37 \\
\hline
\end{tabular}

Table II. 2. Consensus Statements

\begin{tabular}{|c|c|c|c|c|c|c|c|c|c|}
\hline \multirow{2}{*}{\multicolumn{2}{|c|}{ Consensus Statements }} & \multicolumn{2}{|c|}{ Factor 1} & \multicolumn{2}{|c|}{ Factor 2} & \multicolumn{2}{|c|}{ Factor 3} & \multicolumn{2}{|c|}{ Factor 4} \\
\hline & & Q-value & $\begin{array}{l}\text { Z-score } \\
(P<0.01)\end{array}$ & Q-value & $\begin{array}{l}\text { Z-score } \\
(P<0.01)\end{array}$ & Q-value & $\begin{array}{l}\text { Z-score } \\
(P<0.01)\end{array}$ & Q-value & $\begin{array}{l}\text { Z-score } \\
(P<0.01)\end{array}$ \\
\hline Demographic & $\begin{array}{l}\text { 25. The productive and } \\
\text { economic management of } \\
\text { forestry companies } \\
\text { diminishes the opportunities } \\
\text { for family producers to } \\
\text { produce, save and progress. }\end{array}$ & -3 & -0.93 & -2 & -0.83 & -1 & -0.32 & -1 & -0.55 \\
\hline Environment & $\begin{array}{l}\text { 11. For the environment, } \\
\text { forestry plantations are better } \\
\text { than other industrial crops in } \\
\text { the area (such as soybeans } \\
\text { and tobacco). }\end{array}$ & -1 & -0.16 & 0 & -0.16 & -2 & -0.63 & 0 & 0.01 \\
\hline
\end{tabular}


Table II. 3. Comparison of statements of greater and lesser differences in the $Z$ score between factor 1 and factor 2 of M FMM

\begin{tabular}{|c|c|c|c|c|}
\hline Statements of greater differences between factors & Sector & Factor 1 & Factor 2 & Difference \\
\hline $\begin{array}{l}\text { 26. The abandonment of farms, by migration of } \\
\text { colonos to the city, allowed the advance of forestry } \\
\text { plantations. }\end{array}$ & Demographic & 1.872 & -0.722 & 2.594 \\
\hline $\begin{array}{l}\text { 3. Forestry plantations were already part of the local } \\
\text { productive activity before the establishment of } \\
\text { companies in the colony. }\end{array}$ & $\begin{array}{l}\text { Own productive } \\
\text { system }\end{array}$ & 1.650 & -1.774 & 3.424 \\
\hline Statements of lesser differences between factors & Sector & Factor 1 & Factor 2 & Difference \\
\hline $\begin{array}{l}\text { 29. Government policies, which promoted forestry } \\
\text { activity have brought economic growth to the region. }\end{array}$ & Government policies & -0.717 & -0.431 & -0.286 \\
\hline $\begin{array}{l}\text { 25. The productive and economic management of } \\
\text { forestry companies diminishes the opportunities for } \\
\text { family producers to produce, save and progress. }\end{array}$ & Demographic & -0.933 & -0.828 & -0.105 \\
\hline $\begin{array}{l}\text { 11. For the environment, forestry plantations are } \\
\text { better than other industrial crops in the area (such as } \\
\text { soybeans and tobacco). }\end{array}$ & Environment & -0.163 & -0.161 & -0.002 \\
\hline $\begin{array}{l}\text { 12. The typical productive activity of the colonos (with } \\
\text { a little bit of everything, pigs, yerba mate, cassava, } \\
\text { etc.) is better for the environment than plantations. }\end{array}$ & Environment & 1.213 & 1.200 & 0.012 \\
\hline $\begin{array}{l}\text { 23. The change in the landscape with the increase in } \\
\text { forestry plantations (companies) contributed to the } \\
\text { colonos migration to cities. }\end{array}$ & Demographic & 0.000 & -0.175 & 0.175 \\
\hline $\begin{array}{l}\text { 10. With forestry activity, earth bugs (worms, beetles, } \\
\text { etc.) die and it is more difficult to find some animals } \\
\text { (pigs, yatei bees) and plants from the forest we use } \\
\text { (for medicine, to eat). }\end{array}$ & Environment & -0.221 & -0.442 & 0.221 \\
\hline $\begin{array}{l}\text { 15. Intensive use of roads causes damage to rural } \\
\text { dwellers. }\end{array}$ & Social & -0.880 & -1.149 & 0.269 \\
\hline
\end{tabular}

Table II. 4. Summary of the characteristics of the main factors of the M FMM analysis.

\begin{tabular}{|c|c|c|c|c|c|c|c|c|c|c|c|}
\hline & & \multicolumn{2}{|c|}{$\begin{array}{c}\text { Factor } 1 \\
\text { The impartials }\end{array}$} & \multicolumn{4}{|c|}{$\begin{array}{c}\text { Factor } 2 \\
\text { The detractors }\end{array}$} & \multicolumn{2}{|c|}{$\begin{array}{l}\text { Factor } 3 \\
\text { Divided opinions: family } \\
\text { production and health }\end{array}$} & \multicolumn{2}{|c|}{$\begin{array}{l}\text { Factor } 4 \\
\text { Divided opinions: } \\
\text { Government, local and } \\
\text { regional production }\end{array}$} \\
\hline \multicolumn{2}{|c|}{ Gender } & Male & Male & Male & Male & Male & Male & Female & Female & Female & Male \\
\hline \multicolumn{2}{|c|}{ Education level } & Primary & Tertiary & Primary & Primary & Primary & Universitary & Tertiary & Primary & Primary & Secondary \\
\hline \multicolumn{2}{|c|}{$\begin{array}{l}\text { Link with the } \\
\text { agriculture } \\
\text { activity }\end{array}$} & Producer & $\begin{array}{l}\text { Son of } \\
\text { producers }\end{array}$ & Producer & Producer & Producer & $\begin{array}{l}\text { Municipal } \\
\text { technician }\end{array}$ & $\begin{array}{l}\text { Municipal } \\
\text { technician }\end{array}$ & Producer & Producer & Producer \\
\hline \multicolumn{2}{|c|}{$\begin{array}{l}\text { Degree of } \\
\text { dependence on } \\
\text { agricultural } \\
\text { activity }\end{array}$} & Primary & Secondary & Primary & Primary & Primary & none & Secondary & Primary & Primary & Secondary \\
\hline \multirow{2}{*}{ Activity } & Primary & Producer & Teacher & Producer & Producer & Producer & $\begin{array}{l}\text { Municipal } \\
\text { staff }\end{array}$ & $\begin{array}{l}\text { Municipal } \\
\text { staff }\end{array}$ & Producer & Producer & $\begin{array}{l}\text { Municipal } \\
\text { technician }\end{array}$ \\
\hline & $\begin{array}{c}\text { Second } \\
\text { ary }\end{array}$ & -..... & -non & Retired & Retired & -....... & -...-...- & Producer & Retired & Retired & Producer \\
\hline \multicolumn{2}{|c|}{ Locality } & Santiago & de Liniers & $\begin{array}{l}\text { Santiago } \\
\text { de Liniers }\end{array}$ & \multicolumn{3}{|c|}{ Esperanza Centro } & $\begin{array}{l}\text { Santiago } \\
\text { de Liniers }\end{array}$ & $\begin{array}{c}\text { Esperanza } \\
\text { Centro }\end{array}$ & $\begin{array}{c}\text { Esperanza } \\
\text { Centro }\end{array}$ & $\begin{array}{c}\text { Santiago de } \\
\text { Liniers }\end{array}$ \\
\hline
\end{tabular}

\section{REFERENCES:}

The degree of dependence on agricultural activity: Principal: main source of livelihood; Secondary: when the satisfaction of family needs is based on another type of productive activity in addition to agricultural activity; None: the informant does not develop agricultural activities.

Productive activity (or of sustenance): Principal: activity that has greater importance in the family sustenance; Secondary: activity that has less importance in the family sustenance. 
Table II. 5. Characteristics of the participants and factorial loads.

\begin{tabular}{|c|c|c|c|c|c|c|}
\hline \multicolumn{7}{|c|}{ Factorial loads of the analysis of M FMM } \\
\hline Participant & Colony & $\begin{array}{l}\text { The degree of } \\
\text { dependence on } \\
\text { agricultural } \\
\text { activity }\end{array}$ & $\begin{array}{c}\text { Factor } 1 \\
\text { The } \\
\text { impartial }\end{array}$ & $\begin{array}{c}\text { Factor } 2 \\
\text { The } \\
\text { detractors }\end{array}$ & $\begin{array}{c}\text { Factor } 3 \\
\text { Divided opinions: } \\
\text { family production } \\
\text { and health }\end{array}$ & $\begin{array}{l}\quad \text { Factor } 4 \\
\text { Divided opinions: } \\
\text { Government, local and } \\
\text { regional production }\end{array}$ \\
\hline Producer, fp & EC & Principal & 0.23 & 0.19 & $0.83^{b}$ & 0.13 \\
\hline Producer, $\mathrm{mp}$ & EC & Principal & -0.02 & $0.61^{b}$ & 0.12 & -0.26 \\
\hline Municipal technician, mu & EC & Ninguno & -0.25 & $0.75^{b}$ & 0.31 & 0.19 \\
\hline Producer, fp & EC & Principal & 0.37 & -0.08 & 0.03 & $-0.77^{b}$ \\
\hline Producer, mp & EC & Principal & 0.23 & $0.70^{b}$ & -0.28 & -0.04 \\
\hline Son of producers, $\mathrm{mt}$ & SL & Secondary & $0.88^{b}$ & -0.14 & 0.13 & 0.07 \\
\hline Municipal technician, $\mathrm{ft}$ & $\mathrm{SL}$ & Secondary & 0.10 & 0.17 & $-0.75^{b}$ & 0.22 \\
\hline Producer, ms & SL & Secondary & 0.36 & -0.14 & -0.05 & $0.76^{b}$ \\
\hline Producer , mp & SL & Principal & 0.40 & $0.59^{b}$ & -0.26 & 0.21 \\
\hline Producer, $\mathrm{mp}^{\mathrm{a}}$ & $\mathrm{SL}$ & Principal & $0.65^{b}$ & 0.33 & -0.03 & -0.11 \\
\hline
\end{tabular}

\section{REFERENCES:}

Gender: $\mathrm{m}=$ =male; $f=$ female. Education level: $p=$ primary; $s=$ secondary; $t=$ tertiary; $u=u n i v e r s i t y . ~ C o l o n y:$ EC=Esperanza Centro; SL=Santiago de Liniers. b Significant factorial loads. 


\section{ADDITIONAL FILES III.}

\section{PERCEPTION OF F FMM COMMUNITIES. Summary of the characteristics of the main emerging points of view.}

The analysis identified the main factors that represent the collective imaginary. Each factor brings together participants with similar views on the issue (from significant factor loads reflecting the degree of agreement). The name assigned to each factor was defined by the authors taking into consideration the theme -or emotional position- emerging in relation to forestry activity and its impact. Table 3 of the article details the reliability, error and percentage of explained values of each factor, as well as the total percentage of explained of the factors considered.

For this FMM, four factors were defined: impartial neighbours; those who intellectualize the problem; those who emphasize the commercial monopoly and those who perceive a dichotomy between family and business activity. Further details are included in tables in this Additional File. Table III. 1. lists distinguishing and characteristic statements that integrate each factor. Table III. 2. details statements expressing consensus between factors in the general issues addressed in the classification (i.e. own productive system, family economy, environment, social, demographic and governmental policies). Table III. 3. analyses statements with greater and lesser differences between factors in detail. Tables III. 4. and III. 5. provide a detail of the characteristics of the neighbours grouped in each of the factors explained.

Among the issues considered to be common and most relevant by the participants of the F FMM, as in the previous case, although to a lower proportion, opposite opinions are generated on the same sentence, which would show a diversity of opinion. This is the case at analysing the way of perceiving the relationship between the development of forestry activity and the increase in jobs, mainly in urban areas (13); the relationship between ruralurban migration and the advance of forest plantations; at considering the effects of fumigation of forest plantations on family production; or at expressing their opinion about competition between companies and small producers. There is agreement with regard to the idea that government policies for regional forestry development favoured large capitals and did not guarantee the well-being of the local population despite the region's economic growth. They argue that the establishment of companies allowed families to diversify their activities and do not perceive that family productive systems have been adversely affected by the hiring of producers in forestry companies. However, they agree that mechanization operated at the expense of labour demand. They agree that forestry plantations were not a part of the family productive activity prior to the establishment of companies in the colony. They do not associate the plantations development with the decrease in the social activity among neighbours. With regards to the marketing of products, they consider that forestry companies monopolise and regulate the conditions. The relationship between forest companies and neighbours is evaluated negatively. They do not see afforestation as the best productive option at a regional and family level and argue that monoculture development negatively affects biodiversity (Additional File IV). 


\section{Factor 1: The Impartials.}

The group does not express a critical view of afforestation, although a viewpoint that highlights the negative impact on the environment emerges weakly. They consider that the multiple productive system, typical of small and medium-sized producers, is better than forestry plantations (12). However, they do not relate the decrease in the volume of water in streams and springs to the extent of this monoculture (9). They point out that the presence of forestry companies does not lead to an increase in the supply of jobs in urban areas (13). They value the impact that government policies had on the development of family economies negatively (30).

The three participants with high loads for this factor (Additional File III) are all from Montecarlo. One is a former producer (P7) while the other two are currently producers; one of the latter is also a technician for the local municipality (P8 and P9) (Table III. 4 and III. 5).

\section{Factor 2: The intellectuals.}

From this viewpoint, a negative opinion of afforestation emerges focused on environmental, demographic and social aspects. Pine monoculture is not perceived as better than other types of monoculture present in the region (11). With regard to the demographic impact, the establishment of forestry companies is conceptually associated with the depopulation of rural areas in a context that is critical to family production (23). In relation to social aspects, they highlight the lack of improvement in roads despite the income generated in the region through intensive forestry exploitation (16).

Of the three informants with high loads for this factor, two are from Montecarlo; one is a former producer and retired rural teacher (P4) and the other is a technician in a rural organization (P10). The third participant is from Eldorado, son of producers, currently dedicated to education (P5). At present, none of them depend economically on agricultural activity (Table III. 4. and III. 5.).

\section{Factor 3: The commercial monopoly.}

In relation to family economy, the local perception represented by this factor is that forestry companies compete with small producers.

The neighbours grouped in this factor are producers who also managed other private properties or a legal entity (agricultural cooperative). One is from Eldorado and one from Montecarlo. Given their experience, both are familiar with marketing conditions and difficulties associated to production. They are therefore likely to be critical of forestry activity, particularly in this regard (Table III. 4. and III. 5.).

\section{Factor 4: Family activity versus activity in companies.}

With regard to the environmental impact, the effects of monoculture on farm production as a consequence of the use of agrochemicals (8) are not perceived negatively. On the social impact, afforestation is perceived at the business level as a source of employment, mainly in 
urban areas (13). In relation to the impact on the own productive system, although the establishment of forestry companies is considered a generator of diversifying alternatives in the family economy, it is also associated with negligence of family productive systems (1).

This factor is represented by two participants: one from Eldorado and the other from Montecarlo, both producers; one of them is an agronomist (Table III. 4. and III. 5.).

In the comparison between factors 1 and 2 that explain a higher percentage of variability (resulting from the Principal Components analysis), the statements with the greatest difference in the $Z$ score refer to the environment and government policies. In the first case, although for both factors forest production is conceptualized as the least friendly (regarding other monocultures such as tobacco or soya) (11), in factor 1 this issue received a score close to zero and was not considered important by the participants grouped here. In the second case, there is no agreement on whether the measures that promoted forestry activity achieved economic growth in the region (29) (Table III. 3.).

The statements of minor differences refer to family economy. Both factors agree that small producers are conditioned on the sale of their products to the market value established by large capitals and that marketing opportunities are inequitable (4). With regard to government policies, they agree that they should further regulate forestry activity (27). In the demographic aspect, they argue that the possibilities of growth at the family level were affected by the activity of forestry companies (25) and agree that afforestation is not the best productive option (19). In the social aspect, companies should contribute financial resources to education and health development and to the restoration of the landscape in the municipalities where they are located (20). With respect to the environment, the effects of monoculture on farm production as a consequence of the use of agrochemicals are perceived negatively (8) (Table III. 3.).

Table III. 1. Distinguishing and characterising statements.

\begin{tabular}{|c|c|c|c|}
\hline \multicolumn{4}{|c|}{ Factor 1: The impartials. } \\
\hline & Distinguishing Statements that match with characterising statements & $\begin{array}{l}\text { Q sort } \\
\text { value }\end{array}$ & $\begin{array}{l}\text { Z-scores } \\
(P<0.01)\end{array}$ \\
\hline \multirow[t]{2}{*}{ Environment } & 7. With large plantations, there are more pests that damage neighboring farms. & 2 & 0.96 \\
\hline & Characterising statements & $Q$ value & Z-score \\
\hline Demographic & $\begin{array}{l}\text { 23. The change in the landscape with the increase in forestry plantations (companies), } \\
\text { contributed to the colonos migration to cities. }\end{array}$ & -3 & -1.68 \\
\hline \multirow[b]{2}{*}{ Environment } & 9. Pines consume a lot of water and the streams dry up. & -4 & -1.30 \\
\hline & $\begin{array}{l}\text { 12. The typical productive activity of the colonos (with a little bit of everything, pigs, yerba } \\
\text { mate, cassava, etc.) is better for the environment than plantations. }\end{array}$ & 4 & 1.53 \\
\hline \multirow{4}{*}{ Social } & 13. With the development of forestry activity there is more work in the village. & -4 & -1.30 \\
\hline & 14. The mechanization of forestry companies decreased the demand for labour. & 3 & 1.23 \\
\hline & 19. Plantations are the best productive activity for the region and local families. & -3 & -1.38 \\
\hline & $\begin{array}{l}\text { 22. The decrease in social activities among the neighbours of the colony (closure of } \\
\text { clubs, abandonment of typical festivities, etc.) is related to the forestry activity } \\
\text { established in the colony. }\end{array}$ & -3 & -1.79 \\
\hline $\begin{array}{l}\text { Own productive } \\
\text { system }\end{array}$ & $\begin{array}{l}\text { 2. The establishment of forestry companies allowed families to have other productive } \\
\text { activities (such as trade, employment, contractors, etc.). }\end{array}$ & 3 & 1.05 \\
\hline Family economy & $\begin{array}{l}\text { 4. Forestry companies monopolize and regulate the marketing conditions of forest } \\
\text { products (wood and pulp). }\end{array}$ & 3 & 1.23 \\
\hline $\begin{array}{l}\text { Government } \\
\text { policies }\end{array}$ & $\begin{array}{l}\text { 30. Despite the region economic growth, government policies do not guarantee the well- } \\
\text { being of the local population. }\end{array}$ & 4 & 1.45 \\
\hline
\end{tabular}


Factor 2: The intellectuals.

\begin{tabular}{|c|c|c|c|}
\hline & Distinguishing Statements that match with characterising statements & $\begin{array}{l}Q \text { sort } \\
\text { value }\end{array}$ & $\begin{array}{l}\text { Z-scores } \\
(\mathrm{P}<0.01)\end{array}$ \\
\hline Demographic & $\begin{array}{l}\text { 23. The change in the landscape with the increase in forestry plantations (companies), } \\
\text { contributed to the migration of colonos to cities. }\end{array}$ & 3 & $1.40^{*}$ \\
\hline Environment & $\begin{array}{l}\text { 11. For the environment, forest plantations are better than other industrial crops in the } \\
\text { area (such as soybeans and tobacco). }\end{array}$ & -3 & $-1.90^{\star}$ \\
\hline \multirow[t]{2}{*}{ Social } & $\begin{array}{l}\text { 16. Forestry companies open up more roads in the colony and this is good for families } \\
\text { living in the area. }\end{array}$ & -4 & $-1.30^{*}$ \\
\hline & Characterising statements & $Q$ value & Z-score \\
\hline \multirow[b]{2}{*}{ Environment } & $\begin{array}{l}\text { 8. Fumigations of forestry plantations damage some family productions (honey, citrus, } \\
\text { corn, cassava, yerba mate). }\end{array}$ & 3 & 1.10 \\
\hline & $\begin{array}{l}\text { 10. With forestry activity, earth bugs (worms, beetles, etc.) die and it is more difficult to } \\
\text { find some animals (pigs, yatei bees) and plants from the forest we use (for medicine, to } \\
\text { eat). }\end{array}$ & 4 & 1.52 \\
\hline \multirow{2}{*}{ Social } & 17. Fumigations and pollen from forestry plantations affect neighbour's health. & 4 & $1.65^{\star}$ \\
\hline & 19. Plantations are the best productive activity both for the region and for local families. & -4 & -1.25 \\
\hline $\begin{array}{l}\text { Own productive } \\
\text { system }\end{array}$ & $\begin{array}{l}\text { 3. Forestry plantations were already part of the local productive activity before the } \\
\text { establishment of companies in the colony. }\end{array}$ & -3 & -1.78 \\
\hline \multirow{2}{*}{ Family economy } & $\begin{array}{l}\text { 4. Forestry companies monopolize and regulate marketing conditions for forest products } \\
\text { (wood and pulp). }\end{array}$ & 3 & 1.05 \\
\hline & 5. Forestry companies compete with small producers in the local market. & -3 & $-1.67^{\star}$ \\
\hline
\end{tabular}

\begin{tabular}{|c|c|c|c|}
\hline & Distinguishing Statements that match with characterising statements & $\begin{array}{l}\text { Q sort } \\
\text { value }\end{array}$ & $\begin{array}{l}\text { Z-scores } \\
(P<0.01)\end{array}$ \\
\hline \multirow[t]{2}{*}{ Family economy } & 5. Forestry companies compete with small producers in the local market. & 3 & $1.28^{\star}$ \\
\hline & Characterising statements & $Q$ value & Z-score \\
\hline \multirow{2}{*}{ Demographic } & $\begin{array}{l}\text { 23. The change in the landscape with the increase in forestry plantations (companies), } \\
\text { contribute to the colonos migration to cities. }\end{array}$ & -3 & -1.92 \\
\hline & $\begin{array}{l}\text { 26. The abandonment of farms, by the migration of colonos to the city, allowed the } \\
\text { advance of forestry plantations. }\end{array}$ & -3 & $-1.37^{\star}$ \\
\hline \multirow[b]{2}{*}{ Environment } & $\begin{array}{l}\text { 8. Fumigations of forestry plantations damage some family productions (honey, citrus, } \\
\text { corn, cassava, yerba mate). }\end{array}$ & 4 & 1.60 \\
\hline & $\begin{array}{l}\text { 10. With forestry activity, earth bugs (worms, beetles, etc.) die and it is more difficult to } \\
\text { find some animals (pigs, yatei bees) and plants from the forest we use (for medicine, to } \\
\text { eat). }\end{array}$ & 3 & 1.51 \\
\hline \multirow{2}{*}{ Social } & 13. With the development of forestry activity there is more work in the village. & -3 & -1.23 \\
\hline & 15. The intensive use of roads causes damage to rural dwellers. & -4 & -1.23 \\
\hline $\begin{array}{l}\text { Own productive } \\
\text { system }\end{array}$ & $\begin{array}{l}\text { 3. Forestry plantations were already part of local productive activity before the } \\
\text { establishment of companies in the colony. }\end{array}$ & -4 & -1.10 \\
\hline Family economy & $\begin{array}{l}\text { 6. The salaries of forestry companies increase the amount of money circulating in the } \\
\text { region and improve commercial activity (buying and selling of food, clothing, telephones, } \\
\text { etc.). }\end{array}$ & 3 & 1.23 \\
\hline $\begin{array}{l}\text { Government } \\
\text { policies }\end{array}$ & 28. Regional forestry development policies favour large capitals. & 4 & 2.01 \\
\hline
\end{tabular}




\begin{tabular}{|c|c|c|c|}
\hline \multicolumn{4}{|c|}{ Factor 4: Divided opinions: Government, local and regional production } \\
\hline & $\begin{array}{l}\text { Distinguishing Statements that match with characterising } \\
\text { statements }\end{array}$ & $\begin{array}{l}Q \text { sort } \\
\text { value }\end{array}$ & $\begin{array}{l}\text { Z-scores } \\
(P<0,01)\end{array}$ \\
\hline Social & $\begin{array}{l}\text { 19. Plantations are the best productive activity both for the region } \\
\text { and for local families. }\end{array}$ & 3 & 1.37 \\
\hline \multirow[t]{2}{*}{$\begin{array}{l}\text { Government } \\
\text { policies }\end{array}$} & 28. Regional forestry development policies favoured large capitals. & -4 & -1.65 \\
\hline & Characterising statements & $\begin{array}{l}Q \text { sort } \\
\text { value }\end{array}$ & $\begin{array}{c}\text { Z-scores } \\
\text { Matching distinguishing } \\
\text { statements with significant } \\
\text { differences are indicated } \\
\text { with an asterisk }(\mathrm{P}<0.05) \text {. }\end{array}$ \\
\hline Demographic & $\begin{array}{l}\text { 26. The abandonment of farms, by migration of colonos to the city, } \\
\text { allowed the advance of forestry plantations. }\end{array}$ & 3 & 1.09 \\
\hline \multirow{3}{*}{ Environment } & $\begin{array}{l}\text { 8. Fumigations of forest plantations damage some family } \\
\text { productions (honey, citrus, corn, cassava, yerba mate). }\end{array}$ & 4 & 1.64 \\
\hline & 9. Pines consume a lot of water and the streams dry up. & 4 & 2.19 \\
\hline & $\begin{array}{l}\text { 10. With the forestry activity, earth bugs (worms, beetles, etc.) die } \\
\text { and it is more difficult to find some animals (pigs, yatei bees) and } \\
\text { plants from the forest we use (for medicine, to eat). }\end{array}$ & -4 & $-1.64^{*}$ \\
\hline Social & $\begin{array}{l}\text { 17. Fumigations and pollen from forestry plantations affect } \\
\text { neighbours health of . }\end{array}$ & 3 & 1.37 \\
\hline \multirow[b]{2}{*}{ Family economy } & $\begin{array}{l}\text { 5. Forestry companies company competes with the small producer } \\
\text { in the local market. }\end{array}$ & -4 & -1.10 \\
\hline & $\begin{array}{l}\text { 6. The salaries of forestry companies increase the amount of } \\
\text { money circulating in the region and improve commercial activity } \\
\text { (buying and selling of food, clothing, telephones, etc.). }\end{array}$ & -3 & $-1.38^{*}$ \\
\hline $\begin{array}{l}\text { Government } \\
\text { policies }\end{array}$ & $\begin{array}{l}\text { 30. Despite the region's economic growth, government policies do } \\
\text { not guarantee the well-being of the local population. }\end{array}$ & -4 & -1.37 \\
\hline
\end{tabular}

Table III. 2. Consensus Statements

\begin{tabular}{|c|c|c|c|c|c|c|c|c|c|}
\hline \multirow{2}{*}{\multicolumn{2}{|c|}{ Consensus Statements }} & \multicolumn{2}{|c|}{ Factor 1} & \multicolumn{2}{|l|}{ Factor 2} & \multicolumn{2}{|c|}{ Factor 3} & \multicolumn{2}{|l|}{ Factor 4} \\
\hline & & Q-value & \begin{tabular}{|l|} 
Z-score \\
$(P<0.01)$
\end{tabular} & Q-value & \begin{tabular}{|l|} 
Z-score \\
$(P<0.01)$
\end{tabular} & Q-value & $\begin{array}{l}\text { Z-score } \\
(P<0.01)\end{array}$ & Q-value & $\begin{array}{l}\text { Z-score } \\
(\mathrm{P}<0.01)\end{array}$ \\
\hline \multirow{3}{*}{ Social } & $\begin{array}{l}\text { 18. When a farmer dedicates to } \\
\text { forestry activity in a company, family } \\
\text { members have less help in caring } \\
\text { for the farm. }\end{array}$ & 0 & -0.11 & 0 & 0.28 & 0 & -0.32 & -1 & -0.14 \\
\hline & $\begin{array}{l}\text { 14. The mechanization of forestry } \\
\text { companies decreased the demand } \\
\text { for labour. }\end{array}$ & 3 & 1.23 & 1 & 0.59 & 0 & 0.23 & 0 & 0.17 \\
\hline & $\begin{array}{l}21 . \text { The relationship between } \\
\text { forestry companies and neighbours } \\
\text { is good. }\end{array}$ & -1 & -0.38 & -2 & -0.93 & 0 & 0.09 & 0 & 0 \\
\hline $\begin{array}{l}\text { Family } \\
\text { economy }\end{array}$ & $\begin{array}{l}\text { 4. Forestry companies company } \\
\text { monopolize and regulate marketing } \\
\text { conditions for forest products (wood } \\
\text { and pulp). }\end{array}$ & 3 & 1.23 & 3 & 1.06 & 1 & 0.60 & 2 & 1.06 \\
\hline
\end{tabular}


Table III. 3. Comparison of statements of greater and lesser differences in the $Z$ score between factor 1 and factor 2 of M MMF

\begin{tabular}{|l|l|l|l|l|}
\hline Statements of greater differences between factors & Sector & Factor 1 & Factor 2 & Difference \\
\hline $\begin{array}{l}\text { 11. Plantations are better for the environment than } \\
\text { other industrial crops in the area (such as } \\
\text { soybeans and tobacco). }\end{array}$ & Environment & -0.010 & -1.902 & 1.892 \\
\hline $\begin{array}{l}\text { 29. Government policies, which promoted forestry } \\
\text { activity, achieved economic growth in the region. }\end{array}$ & Government policies & 0.781 & -0.924 & 1.705 \\
\hline
\end{tabular}

\begin{tabular}{|l|l|l|l|l|}
\hline Statements of lesser differences between factors & Sector & Factor 1 & Factor 2 & Difference \\
\hline $\begin{array}{l}\text { 4. Forestry companies monopolize and regulate } \\
\text { marketing conditions for forest products (wood } \\
\text { and pulp). }\end{array}$ & Family economy & 1.229 & 1.055 & 0.174 \\
\hline $\begin{array}{l}\text { 27. Government policies should further regulate } \\
\text { forestry activity. }\end{array}$ & Government policies & 1.010 & 0.924 & 0.086 \\
\hline $\begin{array}{l}\text { 25. The productive and economic management of } \\
\text { forestry companies diminished the opportunities } \\
\text { for family producers to produce, save and } \\
\text { progress. }\end{array}$ & Demographic & 0.416 & 0.428 & -0.012 \\
\hline $\begin{array}{l}\text { 19. Plantations are the best productive activity } \\
\text { both for the region and local families. }\end{array}$ & Social & -1.385 & -1.248 & -0.137 \\
\hline $\begin{array}{l}\text { 20. Forestry companies should contribute more to } \\
\text { the development of education, health and } \\
\text { landscape restoration in the municipalities where } \\
\text { they are located. }\end{array}$ & Social & 0.125 & 0.321 & -0.196 \\
\hline $\begin{array}{l}\text { 8. Fumigations of forestry plantations damage } \\
\text { some family productions (honey, citrus, corn, } \\
\text { cassava, yerba mate). }\end{array}$ & Environment & 0.832 & 1.099 & -0.267 \\
\hline
\end{tabular}

Table III. 4. Summary of the characteristics of the main factors of the M FMM analysis.

\begin{tabular}{|c|c|c|c|c|c|c|c|c|c|c|c|}
\hline \multirow{2}{*}{\multicolumn{2}{|c|}{ Gender }} & \multicolumn{3}{|c|}{$\begin{array}{l}\text { Factor } 1 \\
\text { The impartials }\end{array}$} & \multicolumn{3}{|c|}{$\begin{array}{l}\text { Factor } 2 \\
\text { The intellectuals }\end{array}$} & \multicolumn{2}{|l|}{$\begin{array}{l}\text { Factor } 3 \\
\text { The } \\
\text { monopoly }\end{array}$} & \multicolumn{2}{|c|}{$\begin{array}{l}\text { Factor } 4 \\
\text { Family activity versus } \\
\text { activity in companies }\end{array}$} \\
\hline & & Male & Male & Male & Female & Male & Female & Male & Male & Male & Male \\
\hline \multicolumn{2}{|c|}{ Education level } & Secondary & University & Secondary & Tertiary & Tertiary & University & Secondary & Primary & Secondary & University \\
\hline \multicolumn{2}{|c|}{$\begin{array}{l}\text { Link with the } \\
\text { agriculture activity }\end{array}$} & $\begin{array}{l}\text { Former } \\
\text { producer }\end{array}$ & Producer & Producer & $\begin{array}{l}\text { Daughter } \\
\text { of } \\
\text { producer }\end{array}$ & $\begin{array}{l}\text { Former } \\
\text { producer }\end{array}$ & $\begin{array}{l}\text { Rural } \\
\text { organization } \\
\text { technician }\end{array}$ & Producer & Ex producer & Producer & Producer \\
\hline \multicolumn{2}{|c|}{$\begin{array}{lr}\text { Degree } & \text { of } \\
\text { dependence } & \text { on } \\
\text { agricultural } & \\
\text { activity } & \end{array}$} & None & Secondary & Primary & None & None & None & Primary & None & Primary & Secondary \\
\hline \multirow{2}{*}{ Activity } & Primary & Commerce & $\begin{array}{l}\text { Municipal } \\
\text { technician }\end{array}$ & Producer & Teacher & $\begin{array}{l}\text { Retired } \\
\text { teacher }\end{array}$ & $\begin{array}{l}\text { Rural } \\
\text { organization } \\
\text { technician }\end{array}$ & Producer & $\begin{array}{l}\text { Retired (ex- } \\
\text { agricultural } \\
\text { cooperative } \\
\text { worker) }\end{array}$ & Producer & $\begin{array}{l}\text { Forestry } \\
\text { engineer }\end{array}$ \\
\hline & $\begin{array}{l}\text { Second } \\
\text { ary }\end{array}$ & & Producer & & -1. & 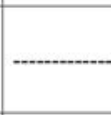 & 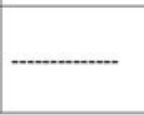 & Retired & 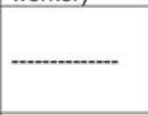 & $\begin{array}{l}\text { Small } \\
\text { producer } \\
\text { market } \\
\text { sales }\end{array}$ & Producer \\
\hline \multicolumn{2}{|c|}{ Locality } & \multicolumn{3}{|c|}{ Montecarlo } & Eldorado & \multicolumn{2}{|c|}{ Montecarlo } & Eldorado & Montecarlo & Montecarlo & Eldorado \\
\hline
\end{tabular}

\section{REFERENCES:}

The degree of dependence on agricultural activity: Principal: main source of livelihood; Secondary: when the satisfaction of family needs is based on another type of productive activity in addition to agricultural activity; None: the informant does not develop agricultural activities.

Productive activity (or of sustenance): Principal: activity that has greater importance in the family sustenance; Secondary: activity that has less importance in the family sustenance 
Table III. 5. Characteristics of the participants and factorial loads

\begin{tabular}{|c|c|c|c|c|c|c|}
\hline \multicolumn{7}{|c|}{ Factorial loads of the analysis of M FMM } \\
\hline Participant & Colony & $\begin{array}{l}\text { The degree of } \\
\text { dependence on } \\
\text { agricultural } \\
\text { activity }\end{array}$ & $\begin{array}{c}\text { Factor } 1 \\
\text { The } \\
\text { impartial }\end{array}$ & $\begin{array}{c}\text { Factor } 2 \\
\text { The } \\
\text { detractors }\end{array}$ & $\begin{array}{l}\text { Factor } 3 \\
\text { Divided opinions: } \\
\text { family production } \\
\text { and health }\end{array}$ & $\begin{array}{l}\quad \text { Factor } 4 \\
\text { Divided opinions: } \\
\text { Government, local and } \\
\text { regional production }\end{array}$ \\
\hline Producer, fp & EC & Principal & 0.23 & 0.19 & $0.83^{\mathrm{b}}$ & 0.13 \\
\hline Producer, $\mathrm{mp}$ & EC & Principal & -0.02 & $0.61^{b}$ & 0.12 & -0.26 \\
\hline Municipal technician, mu & EC & Ninguno & -0.25 & $0.75^{b}$ & 0.31 & 0.19 \\
\hline Producer, fp & EC & Principal & 0.37 & -0.08 & 0.03 & $-0.77^{b}$ \\
\hline Producer, $\mathrm{mp}$ & EC & Principal & 0.23 & $0.70^{\mathrm{b}}$ & -0.28 & -0.04 \\
\hline Son of producers, $\mathrm{mt}$ & $\mathrm{SL}$ & Secondary & $0.88^{b}$ & -0.14 & 0.13 & 0.07 \\
\hline Municipal technician, $\mathrm{ft}$ & SL & Secondary & 0.10 & 0.17 & $-0.75^{b}$ & 0.22 \\
\hline Producer, ms & SL & Secondary & 0.36 & -0.14 & -0.05 & $0.76^{\mathrm{b}}$ \\
\hline Producer, $\mathrm{mp}$ & SL & Principal & 0.40 & $0.59^{\mathrm{b}}$ & -0.26 & 0.21 \\
\hline Producer, $\mathrm{mp}^{\mathrm{a}}$ & SL & Principal & $0.65^{b}$ & 0.33 & -0.03 & -0.11 \\
\hline
\end{tabular}

\section{REFERENCES:}

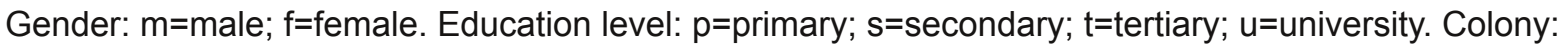
$E C=E s p e r a n z a$ Centro; SL= Santiago de Liniers. $b$ Significant factorial loads. 


\section{ADDITIOAL FILES IV. General valuation assigned to statements by participants neighbouring the three FMM.}

\begin{tabular}{|c|c|c|c|c|c|}
\hline & & \multirow[t]{2}{*}{ Valuation assigned to statements by MMF matrix } & \multicolumn{3}{|c|}{ FMM valuation } \\
\hline & & & $\mathrm{L}$ & $M$ & \\
\hline \multirow{3}{*}{ 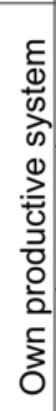 } & 1. & $\begin{array}{l}\text { Due to the offer of new jobs, with the establishment of } \\
\text { forestry companies, the inhabitants neglected some } \\
\text { productive activities in their farms. }\end{array}$ & $\mathrm{N}$ & & \\
\hline & 2. & $\begin{array}{l}\text { The establishment of forestry companies allowed } \\
\text { families to have other productive activities (such as } \\
\text { trade, employment, contractors, etc.). }\end{array}$ & & & $\mathrm{Y}$ \\
\hline & 3. & $\begin{array}{l}\text { Forestry plantations were already part of the local } \\
\text { productive activity before the establishment of } \\
\text { companies in the colony. }\end{array}$ & $\mathrm{N}$ & $\mathrm{Y} / \mathrm{N}$ & $\mathrm{N}$ \\
\hline \multirow{3}{*}{ 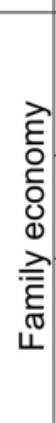 } & 4. & $\begin{array}{l}\text { Forestry companies monopolize and regulate the } \\
\text { marketing conditions of forestry products (wood and } \\
\text { pulp). }\end{array}$ & $\mathrm{Y}$ & & $\mathrm{Y}$ \\
\hline & 5. & $\begin{array}{l}\text { Forestry companies compete with the small producers } \\
\text { in the local market. }\end{array}$ & $\mathrm{N}$ & $\mathrm{N}$ & $\mathrm{Y} / \mathrm{N}$ \\
\hline & 6. & $\begin{array}{l}\text { The salaries of forestry companies increase the } \\
\text { amount of money circulating in the region and improve } \\
\text { commercial activity (buying and selling of food, } \\
\text { clothing, telephones, etc.). }\end{array}$ & & & \\
\hline \multirow{6}{*}{ 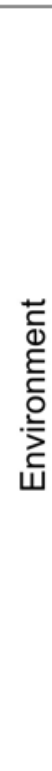 } & 7. & $\begin{array}{l}\text { With large plantations, there are more pests that } \\
\text { damage neighbouring farms. }\end{array}$ & & $\mathrm{Y} / \mathrm{N}$ & \\
\hline & 8. & $\begin{array}{l}\text { Fumigations of forestry plantations damage some } \\
\text { family productions (honey, citrus, corn, cassava, yerba } \\
\text { mate). }\end{array}$ & & & $\mathrm{Y} / \mathrm{N}$ \\
\hline & 9. & Pines consume a lot of water and the streams dry up. & & $\mathrm{Y}$ & \\
\hline & 10. & $\begin{array}{l}\text { With forestry activity, earth bugs (worms, beetles, etc.) } \\
\text { die and it is more difficult to find some animals (pigs, } \\
\text { yatei bees) and plants from the forest we use (for } \\
\text { medicine, to eat). }\end{array}$ & & & $\mathrm{Y}$ \\
\hline & 11. & $\begin{array}{l}\text { Plantations are better for the environment than other } \\
\text { industrial crops in the area (such as soybeans and } \\
\text { tobacco). }\end{array}$ & & $\mathrm{N}$ & \\
\hline & 12. & $\begin{array}{l}\text { The typical productive activity of the colonos (with a } \\
\text { little bit of everything, pigs, yerba mate, cassava, etc.) } \\
\text { is better for the environment than plantations. }\end{array}$ & & $\mathrm{Y}$ & \\
\hline \multirow{4}{*}{$\begin{array}{l}\overline{\frac{\pi}{0}} \\
\dot{D}\end{array}$} & 13. & $\begin{array}{l}\text { With the development of forestry activity there is more } \\
\text { work in the colony. }\end{array}$ & & & $\mathrm{Y} / \mathrm{N}$ \\
\hline & 14. & $\begin{array}{l}\text { The mechanization of forestry companies decreased } \\
\text { the demand for labour. }\end{array}$ & & & $\mathrm{Y}$ \\
\hline & 15. & $\begin{array}{l}\text { The intensive use of roads causes damage to rural } \\
\text { dwellers. }\end{array}$ & & & \\
\hline & 16. & $\begin{array}{l}\text { Forestry companies open more roads in the colony and } \\
\text { this is good for families living in the area. }\end{array}$ & $\mathrm{N}$ & & \\
\hline
\end{tabular}




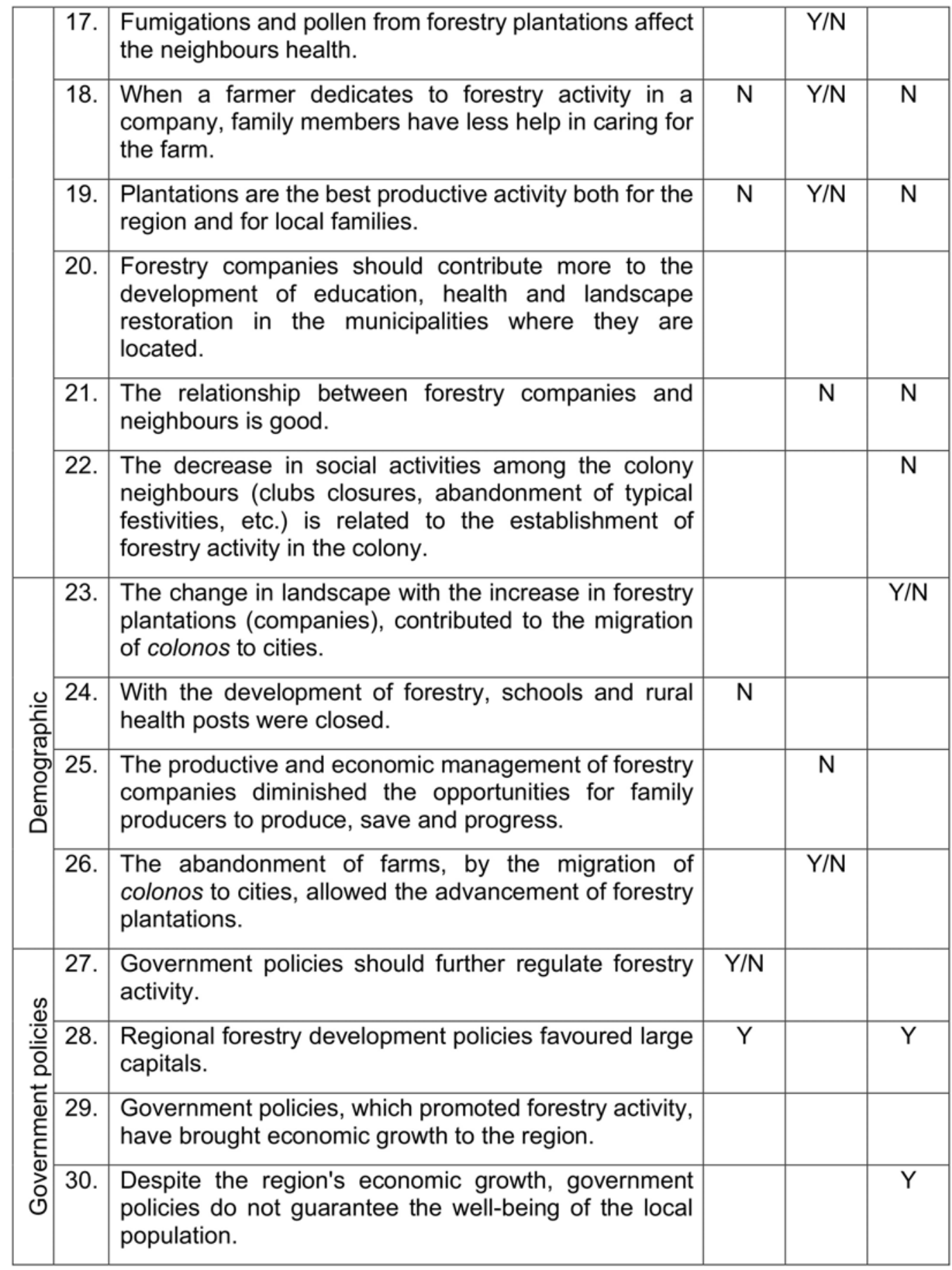

\section{REFERENCES:}

$\mathrm{N}$ : disagreement; $\mathrm{Y}$ : agreement; $\mathrm{Y} / \mathrm{N}$ : lack of consensus. Empty cells indicate non-emergent statements in the valuations of the group. 